Grant-in-Aid for Scientific Research (S)

Real Estate Markets, Financial Crisis, and Economic Growth : An Integrated Economic Approach

Working Paper Series No.41

\title{
Lending Pro-Cyclicality and Macro-Prudential Policy: Evidence from Japanese LTV Ratios
}

\author{
Arito Ono \\ Hirofumi Uchida \\ Gregory F. Udell \\ and \\ lichiro Uesugi
}

February, 2016

HIT-REFINED PROJECT

Institute of Economic Research, Hitotsubashi University

Naka 2-1, Kunitachi-city, Tokyo 186-8603, JAPAN

Tel: +81-42-580-9145

E-mail: hit-refined-sec @ier.hit-u.ac.jp

http://www.ier.hit-u.ac.jp/hit-refined/ 


\title{
Lending Pro-Cyclicality and Macro-Prudential Policy: Evidence from Japanese LTV Ratios ${ }^{\dagger}$
}

\author{
Arito Ono \\ Faculty of Commerce, Chuo University \\ 742-1 Higashinakano, Hachioji, Tokyo 192-0393, Japan. Email: a-ono@tamacc.chuo-u.ac.jp
}

Hirofumi Uchida ${ }^{\ddagger}$

Graduate School of Business Administration, Kobe University

2-1 Rokkodai, Nada, Kobe 657-8510, Japan. Email: uchida@b.kobe-u.ac.jp.

Gregory F. Udell

Kelley School of Business, Indiana University

East $10^{\text {th }}$ Street, Bloomington, 47405, IN, USA. Email: gudell@indiana.edu.

Iichiro Uesugi

Institute of Economic Research, Hitotsubashi University

2-1 Naka, Kunitachi, Tokyo 186-8603, Japan. Email: iuesugi@ier.hit-u.ac.jp

\footnotetext{
${ }^{\dagger}$ Earlier versions of this paper have been presented at HIT-TDB-RIETI workshop, Hitotsubashi Univ., Bank ofJ apan, Kobe, DBJ-RICF, MEW, 2013 FMA Europe, FRBSan Francisoo, Stockholm School of Eoon., 2013 Macroeconomics Conf., NUS, Bangor Univ., FDIC, Bank of Portugal, FRB Kansas City, 50 th Bank Structure Conf., Conduding Conf. of the Macro-prudential Research Network of the European System of Central Banks, 3rd MoFiR Workshop, ABFER 2014 Annual Conf., DePaul Univ., Villanova Univ. and BOJ-IMES. Theauthors thankG. Barlevy, A. Berger, M. Berka, L. Black, C. Brown, T. Duprey, E. Ergungor, E. Fukuda, T. Funuta, M. Giannetti, M. Hanazaki, T. Hatakeda, M. Hon, T. Hoshi, K. Hosono, D. Ikeda, T. Inui, R.Jain, C. Kahn, S.B. Kim, K. Kobayashi, T. Komoda, T. Kurozumi, M. Kowalik, S. Lin, D. Miyakawa, J.I. Nakamura, K. Nakamura, E. Ors, S. Otani, A. Rose, M. Saito, K. Schaeck, T. Soma, A. Srinivasan, M. Summer, B. Tanyen, Y. Teranishi, Y. Tsutsui, Y. Udhida, M. Usui, L. Wall, K. Watanabe, Y. Yasuda, and K. Yoshimura, and seminar participants for useful comments, C. Shimizu and Y. Saita for providing land priœe data, M. Hazama, T. Kimiwada, W. Toyama, S. Mizohata, K. Matsuda, and C. Kwak for superb research assistanœe, Teikoku Databank, Ltd. for data provision, and the Grant-in-Aid for Scientific Research (S, \#25220502 and B, \#24330103) from J SPS, the "Designing Industrial and Financial Networks to Achieve Sustainable Eoonomic Grouth" project under the Ministry of Education, Culture, Sports, Scienœe and Technology's program "Promoting Social Scienœ Research Aimed at Solutions of Near-Future Problems," and RIETI. The views expressed in this paper are ours and do not necessarily reflect those of any of the institutions with which we are affiliated.

${ }^{\ddagger}$ ComespondingAuthor.
} 


\title{
Lending Pro-Cyclicality and Macro-Prudential Policy: Evidence from Japanese LTV Ratios
}

\begin{abstract}
Using a unique micro dataset compiled from the real estate registry in Japan, we examine more than 400,000 loan-to-value (LTV) ratios for business loans to draw implications for the efficacy of caps on LTV ratios as a macro-prudential policy measure. We find that the LTV ratio exhibits counter-cyclicality through the business cycle. We also find that borrowers obtaining high-LTV loans performed no worse ex-post than those with lower LTV loans. Our findings imply that a fixed cap on LTV ratios might not only be ineffective in curbing loan volume in boom periods but also inhibit well-performing firms from borrowing.
\end{abstract}

Keywords: loan-to-value (LTV) ratios, pro-cyclicality, macro-prudential policy, bubble

JEL classification codes: G28, R33, G21, G32 


\section{Introduction}

The recent financial crisis with its epicenter in the U.S. followed a disastrous financial crisis in Japan more than a decade before. These two crises centered on bubbles in real estate prices that affected business loans secured by real estate and mortgages. In Japan banks mostly suffered from damage in the business sector, while in the U.S. large banks mostly suffered from damage in the household sector and smaller banks were significantly affected by damage in commercial real estate lending.

It is probably not an exaggeration to argue that these crises shattered the illusion that the Basel framework - specifically Basel I and Basel II - had ushered in a new era of financial stability. Following the first of these crises, the Japanese crisis, a search began for policy tools that would reduce the probability of future crises and minimize the damage when they occur. Consensus began to build in favor of countercyclical macro-prudential policy levers (e.g., Kashyap and Stein 2004), such as dynamic loan loss provisioning and a countercyclical capital buffer. ${ }^{2}$

More recently, however, the global financial crisis that spread from the U.S. casted doubt on the efficacy of some of these tools. Dynamic loan loss provisioning failed to prevent the Spanish banking crisis, with new evidence even suggesting that it may have promoted risk-taking (Illueca, Norden and Udell 2014). Likewise, doubts on capital requirements as macro-prudential tools have been raised in light of "leaks" in the banking system via shadow banking and other channels (Aiyar, et al. 2014).

In this paper, we focus on a macro-prudential policy lever of another kind - caps on LTV (loan-to-value) ratios. The LTV ratio, defined as L (loan amount) over V (value

\footnotetext{
2 This abstracts from an ongoing debate over the interaction of monetary and macro-prudential policiesin achievingfinancial stability (e.g., Svensson2012, Maddaloni and Peydró 2013).
} 
of assets pledged as collateral), has long been used in loan underwriting as a measure of lenders' risk exposure. Imposing a regulatory cap on LTV ratios in real estate-based lending has become one of the most prominent instruments in the macro-prudential policy toolbag (see e.g., FSB 2012). In fact, the caps have already been implemented in a number of countries. ${ }^{3}$ The caps are viewed as having macro-prudential impact through two channels (CGFS 2012): (1) "strengthen[ing] the resilience of the financial system” by decreasing loans’ probability of default (PD) and loss-given-default (LGD), which we call the risk channel in this paper, and (2) "restrict[ing] the quantity of credit by limiting the funding available for certain borrowers” to dampen growth in real estate prices, which we call the pricing channel. ${ }^{4}$

Our aim is to look retrospectively at LTV ratios in real estate-based lending in the business sector in Japan during the bubble period and the bust period that followed. Our goal is to analyze (counterfactually) the efficacy of a simple LTV cap in Japan in terms of the risk channel. ${ }^{5}$ Specifically we assess whether LTV caps would have counterfactually worked in Japan focusing on the type of loans most responsible for the systemic damage inflicted on the banking sector, i.e., business loans secured by real estate that ultimately resulted in a massive amount of bank charge-offs by Japanese banks. ${ }^{6}$

\footnotetext{
${ }^{3}$ Acoording to a survey conducted by the IMF in 2010, 20 out of 49 countries, especially those in Asia (Hong Kong, Korea, etc.) and Europe (Norway, Sweden, etc.), use caps on LTV ratios as a macro-prudential instrument (Lim, et al. 2011). Some countries do not directly impose hard limits on LTV ratios, but tryinstead to incentivizelow LTV loans by settinglower capital charges on loans with lowerLTV ratios (FSB2011).

${ }^{4}$ Seesection 2.1 formoreon theobjectives of LTV caps.

${ }^{5}$ While we focus on a simple (i.e., unoonditional) LTV cap, not all LTV cap regulations and proposals are of this form. Lim et al. (2011) shows that among 20 countries that imposecaps on LTV ratios, 11 countries set fixed caps while 9 countries adopt time-varying caps. Someproposals advocate implementing LTV caps that change in a oountercydical fashion by linking them, for example, to housing prices (e.g., Crowe et al. 2013). Our analysis could be viewed as an investigation into whether simpleLTV caps should be rejected in favor of conditional LTV caps.

${ }^{6}$ Note that the current global debate on LTV caps outside of the J apanese context is centered on residential mortgages. Wediscuss the similarities and differences between LTV caps on business
} 
Using data that includes detailed information on over 400,000 business loans secured by real estate extended from 1975 to 2009, we examine whether LTV ratios evolved in a pro-cyclical manner. We also compare the ex post performance of business borrowers with high versus low LTV loans in order to analyze whether a simple LTV cap would have limited the availability of credit to risky borrowers.

By way of preview our results suggest that a simple (i.e., unconditional) LTV cap would not have been effective if it had been (counterfactually) implemented in Japan during the bubble period. From our univariate tests that reach back to the beginning of the real estate bubble we find, surprisingly, that the LTV ratio was countercyclical, not pro-cyclical, at least until the early 2000s, suggesting that a simple LTV cap would not have been binding during the bubble period. This finding of pro-cyclicality holds even in a multivariate framework in which we control for loan, firm, and lender characteristics, and key policy variables. ${ }^{7}$ Also surprisingly we find in other tests that the ex post performance of high LTV loans was no worse than that of low LTV loans, and in some cases better, suggesting that imposing LTV caps is potentially harmful in some cases. Taken together, these results shed doubt on the effectiveness of LTV caps as a macro-prudential policy instrument.

To the best of our knowledge, our paper is the first empirical study that examines the efficacy of LTV caps using a loan level micro dataset. ${ }^{8}$ Because most previous studies of LTV caps used aggregate data (e.g., cross-country or city-level data), they

loans and on mortgages in section 2.2.

${ }^{7}$ We note here that data limitations do not permit a multivariate analysis that spans the entire pre-bubble/post-bubblebusiness cyclical as we onducted in our univariateanalysis.

${ }^{8}$ Igan and Kang (2011) (for Korea) and Laufer (2014) (for U.S.) use micro data to study the effect of LTV caps on residential mortgages on housing demand and pricing. Basten and Koch (2014) analyze the Basel III countercyclical capital buffer and its interaction with LTV caps on Swiss residential mortgage priaing. Unlike our paper these analyses of the LTV cap mainly focus on the pricing channel while wefocus on therisk channel (seesubsection 2.2). 
could not evaluate the ex-post performance of borrowers that were (or would have been) rationed by an LTV cap. Thus our paper contributes to the ongoing debate on the efficacy of LTV caps as a macro-prudential policy tool by providing evidence on its potential drawbacks.

The remainder of our paper is composed as follows. The next section provides some context for our analysis by discussing the objectives of LTV caps and the differences in the caps on mortgages and business loans. Section 3 provides details on our data. Section 4 analyzes the cyclicality of LTV ratios. Section 5 investigates the ex post performance of high LTV loans. Section 6 concludes the paper with some policy implications.

\section{The context: LTV caps and our analysis}

\subsection{The objectives of LTV caps $^{9}$}

The main goal of macroprudential policies is "to reduce systemic risk, defined as the risk of widespread disruptions to the provision of financial services that have serious negative consequences for the real economy" (CGFS 2012). In this regard macroprudential policy focuses on market, or economy-wide, interactions, which contrasts with microprudential policy focusing on the risk of individual financial institutions, taking the rest of the market/economy as given. To reduce systemic risk, there are two objectives of macroprudential policy (which are not mutually exclusive): (i) strengthening the resilience of the financial system to economic downturns and other

\footnotetext{
${ }^{9}$ This section owes much to CGFS $(2010,2012)$.
} 
aggregate shocks, and (ii) limiting the build-up of financial risks (by "leaning against the financial cycle”) (CGFS 2010).

Among the various policy instruments that might accomplish these objectives, LTV caps are one of the tools that attract much attention. The caps are designed to function through two main transmission channels (CGFS 2012). ${ }^{10}$ In the first channel, which is to meet objective (i) above, LTV caps are expected to increase the resilience of the banking system by directly decreasing both the probability of default (PD) and the loss-given-default (LGD) of the banking industry's loan portfolio. Claims are often maid that the surges in real estate prices that accompany credit booms invite excessive risk-taking by banks using high LTV loans underwritten with lax bank lending standards (e.g., Borio et al. 2001; Berger and Udell 2004). Through the imposition of an LTV cap, regulators seek to reduce banking industry risk exposure and thereby minimize systemic risk. In this paper, we briefly call this channel, the risk channel of LTV caps.

The second transmission channel of an LTV cap is to meet objective (ii) through its “impact on the credit cycle” (CGFS 2012). LTV caps restrict the quantity of credit by limiting the funding available for certain types of borrowers, and so they can potentially reduce land/housing demand and hence their prices. Theoretical work by Stein (1995) shows that LTV ratios play an important role in amplifying shocks to borrowers and to the housing market. ${ }^{11}$ Consistent with this prediction, empirical studies have consistently found that the effects of income shocks on house prices and/or mortgage borrowing are larger in countries/cities and in periods where LTV ratios are

\footnotetext{
10 In addition to these two mechanisms, CGFS (2012) also disausses the effectiveness of macro-prudential instruments by changingmarket expectations (expectations-based effects).

${ }^{11}$ There are some studies that examine welfare implications for introducing LTV caps (see, for example, Quint and Rabanal 2014 and referenoes therein).
} 
higher, suggesting that the strength of a "financial accelerator" mechanism is positively associated with LTV ratios (Lamont and Stein 1999, Almeida et al. 2006, Lim et al. 2011). Imposing caps on LTV ratios might constrain this accelerator mechanism. For brevity, we call this channel that works through real estate prices the pricing channel.

The effectiveness of LTV caps through the risk channel and/or through the pricing channel is ultimately an empirical question. However, there is a paucity of empirical work in this regard. The present paper is to address a big component of this gap.

\subsection{LTV caps on residential mortgages vs. LTV caps on business loans}

While the current debate on LTV caps is centered on residential or commercial mortgages, we focus on LTV ratios in business lending. We believe that this focus is interesting for two important reasons.

First, LTV caps can be applied (theoretically) to many other types of loans secured by real estate. In most countries real estate is very often pledged as collateral in general business lending, especially for small and midsized enterprises (SMEs), even when the purpose of the loan is not to purchase the real estate itself (Berger and Udell 2006, Beck et al. 2008). ${ }^{12}$ In Japan as well, loans secured by real estate are the most common form of business lending. ${ }^{13}$ Lenders use LTV ratios in underwriting these loans just as they do in residential mortgage underwriting and so it is just as feasible to apply LTV caps to

${ }^{12}$ LTV caps could further be applied to other types of lending secured by assets other than real estate, e.g., consumer lending to finanœe automobile purchases, and business loans lent against acoounts reeeivable, inventory and equipment (Berger and Udell 2006). For these types of loans lenders typically set policies on LTV ratios as part of their underwriting standards.

${ }^{13}$ Although we do not have precise figures on the fraction of SME loans that are secured by real estate, the fraction of SMEs that pledged real estate collateral to any lender was 51.9\% duning 2007-2010 based on the database used in this paper (see Ono etal. 2015.). The figuremight have been even higher during the bubble period, because the J apanese govemment has urged banks to avoid an "excessive" reliance on oollateral and personal guarantees when extending loans to SMEs sinœ2003 (see subsection 4.2.5). 
business loans secured by real estate. In fact, some countries (e.g., Singapore) now impose LTV caps irrespective of the types of loans (CGFS 2012, Lim et al. 2011).

Second, and more importantly, the relevant counterfactual in the context of the Japanese financial crisis in terms of macro-prudential policy tools is whether LTV caps would have worked in business lending. As mentioned above, excessive bank risk-taking through loans secured by real estate is considered one of the primary causes of the credit bubble and the bad loan problems in Japan (e.g., Ueda 2000). During the bubble period, banks were thought to have underwritten high-LTV business loans with lax lending standards anticipating surging real estate prices (e.g., Yoshida 1994). Thus, analyzing the (counterfactual) efficacy of an LTV cap in business lending in Japan addresses directly the issue of whether this macro-prudential policy tool might have worked in preventing the financial crisis that wreaked havoc on the world's second largest economy. ${ }^{14}$

However, we will be careful to qualify the applicability of our findings in the business sector to the efficacy of LTV caps on residential and commercial mortgages. Among the two channels of caps on LTV ratios indicated above, the risk and the pricing channels, our analysis of LTV caps on business loans in Japan will necessarily be concentrated only on the former, i.e., on whether simple LTV caps in business lending would have dampened the build-up of systemic risk in the banking system. This is because for most loans in our sample, the purpose was not to finance the purchase of the real estate that secures the loan - even though the loan was secured by real estate. Thus,

\footnotetext{
${ }^{14}$ The Japanese govemment did consider introducing LTV caps for loans seaured by real estate in the early 1990s to deal with the real estate bubble (Council of Land Policy 1990). In hindsight, however, only a ceiling on the amount of loans to real estatefirms was implemented. We control for this policyin our analysis (seesubsection 4.2.5).
} 
any effect on demand for, or prices of, real estate, is, at most, indirect. ${ }^{15}$ While our data are not well-suited to analyze the pricing channel, they offer a unique opportunity to analyze the risk channel. ${ }^{16}$

\section{Data and the definition of LTV ratios}

\subsection{Data}

Our data contain 420,889 total observations on collateral registrations during the period from 1975 to 2009. Our dataset is constructed from a very large database on Japanese firms compiled by the Teikoku Databank (TDB), the largest credit information provider in Japan. The sample firms in this database are mostly SMEs, because SMEs are the target for TDB's credit research. ${ }^{17}$ The database contains very detailed information on the collateral registrations which TDB extracts from the official real estate registry. This registry is based on the Real Property Registration Act, and compiles information on each piece of real property regarding its description (e.g., specifications on property and related buildings), associated property rights (e.g., ownership and security interests), and any transfer and/or termination of rights that are also recorded in this official registry.

For any real property owned by a firm or its CEO, TDB acquires from the official registry its address, acreage, type of land (e.g., building site or paddy field), type of

${ }^{15}$ On the pricing channel, some studies on residential mortgage investigate or casually report the relationship between lending and property prioes, and thereby examine the implications of imposing an LTV cap on the credit cycle, although they rely on aggregated data and/ or they only check bivariate correlations (e.g., Gerlach and Peng 2005, Iacoviello 2005, Igan and Kang 2011, Barlevy and Fisher 2012, Vandenbusscheetal. 2013, Kuttnerand Shim 2013).

${ }^{16}$ In one test we use a subset of our loans to offer some results that may be suggestivein terms of thepricing channel.

17 Given that the TDB dataset covers almost one third of the entire universe of firms in Japan (see Ono et al. 2015) and that SMEs dominate the business sector in J apan - as in virtually every other economy- our sample is likely representative of the J apanese business sector. 
building (e.g., office, residential or industrial), its ownership, and most importantly for our analysis, whether it is pledged as collateral. Collateral information collected by TDB includes the claim holder(s), the debtor(s), the amount of loans against which the collateral is pledged, and the date it was registered. ${ }^{18}$

Unfortunately, TDB does not collect some of the information contained in the official real estate registry. It does not collect information on seniority when there are multiple claim holders (i.e., first, second or lower liens), so we assume that a claim holder is senior if the date of its registry predates those of the others. ${ }^{19}$ Also, TDB only records registration information that is effective when it conducts credit research on the firm, so registration information is erased from the TDB database, and we cannot trace the history of registration information for a piece of property. Finally, the TDB database does not specify whether a piece of real estate that is pledged as collateral is associated with a business loan or a loan to the CEO/owner to finance a residence, so we distinguish them using other information. ${ }^{20}$

In Japan, collateral takes one of two types: ordinary collateral and ne-tanpo. The former is like collateral pledged in other countries, but the latter, also frequently used in Japan, is different. It is associated with repeated lending such as loans for working capital. As the label implies ("ne" means root and "tanpo" means collateral), once ne-tanpo is

${ }^{18}$ Because our sample firms are mostly small and medium-sized firms, most of the loans are not syndicated loans that are typically targeted forlargeborrowers.

${ }_{19}$ If therearemultipleregistrations at the same date, weassumethat they have the same priority. ${ }^{20}$ Specifically, we first dassify all of the loans secured by ne-tanpo (see below) as business loans, because ne tanpo is usually not used for residential loans. Seoond, loans are also dassified as business loans if their debtors are firms (not their CEOs). Third, if the debtor(s) are the firm's CEOs or board members, we then check whether the firm uses the related personal property as collateral. If this is the case, we classify them as business loans. Finally, if information on the identity of debtors is not available, we exclude the observation from the sample because it is difficult to determine whether the relevant loan is a business loan or a residential one. The number of observations thereby identified as residential loans is 37,352. Ono etal. (2013) discuss theevolution of LTV ratios for theseresidential loans. 
pledged, it remains pledged to the lender and will automatically secure any future loans extended by the same lender to the borrower up to a specified maximum, until its registration is "released" (i.e., terminated). ${ }^{21}$ Thus, the loan balance secured by ne-tanpo fluctuates (or revolves), although the property that is pledged stays the same. The main motivation to use ne-tanpo is to avoid the collateral-related transactions cost for serial borrowings in the spot market. We can identify whether a piece of collateral is ne-tanpo.

Although the richness of the information on real estate registrations in the TDB database is unprecedented in the literature, there are several caveats to using these data that stem from sample selection. First, TDB's database neither covers all of the real estate that a firm (and its CEO) owns, nor covers registration of all sample firms. For firms in its database TDB always collects registration information on a firm's headquarters and its CEO's residence, but data on the other real estate that the firm or its CEO possesses is generated on demand only. Also, TDB's research on the real estate registry is mandatory for SMEs, but for listed and/or large firms (those with the amount of equity capital larger than 100 million yen (roughly $\$ 1.25$ million) and with the number of employees larger than 100), the research is again made on demand only.

Second, and most importantly, although we have data on collateral from 1975 to 2009, we only have pre-2008 data if they appear in the most recent credit report that TDB compiled during the period from 2008 to $2010 .^{22}$ To put it differently, all of the registrations in our sample consist of those that existed in the registry from 2008 to 2010,

${ }^{21}$ There is no automatic expiration date for Netanpo, and unlike lines of credit, ne-tanpo is not associated with a specific commitment to lend in thefuture.

${ }^{22}$ Wedo have some observations for collateral that was registered before 1975 and after 2009, but wedo not use them because of the small number of observations. 
and so those registered before 2007 are included only when they remained registered until at least 2008. ${ }^{23}$ Thus, our data are synthetic in the same sense that Petersen and Rajan’s (2002) data are synthetic. ${ }^{24}$ In some cases TDB conducted credit searches on a firm several times during the 2008-2010 period. In such cases, we only use the most recent data, because changes in the names of the addresses (e.g., street and city names), which most likely occur because of municipal mergers, make it difficult to track the same land in constructing our panel data set.

This cross-sectional-like nature of our data has two shortcomings. First, we cannot exploit data variation in time series dimensions to control for loan, borrower, or lender fixed effects. Second, we might suffer from a survivorship bias problem. In our dataset, "bad" firms that went bankrupt and were liquidated before 2008 are not included. Registration information on repaid "good loans" that were removed from the registry are not included as well. In our regressions, we try to address these shortcomings by controlling for as many firm- and loan-characteristics as possible.

We use information on LTV ratios for our 420,889 total observations on collateral registrations from 1975 to 2009 . These observations are to be used for the univariate analysis (section 4.1). For a subset of 59,125 of these firms, we also have financial statement information. This subset of 59,125 observations is used in our regression analyses (section 4.2). ${ }^{25}$ In Figure 1 we report the number of observations per year used

\footnotetext{
${ }^{23}$ A collateral registered in 1999, for example, would be removed from the TDB database if the loan was paid off and the seaunity interest in the property was terminated as a result. Likewisea bankruptfirm would beremoved.

${ }^{24}$ Petersen and Rajan (2002) use data on the year a firm began a relationship with a given lender, but the data set is conditioned on the firm existing in a specific later year (year 1993) where the information is obtained. Thus, firms that did not survive until 1993 are not included in their sample.

${ }^{25}$ We have additional variables for lender characteristics from lenders' financial statements, but the statements are available for a smaller number of observations. However, even when we add
} 
in both our univariate and regression analysis. This provides an indication of the magnitude of our missing observations that might drive a survivorship bias. The figure shows that the number of observations for our univariate analysis at the beginning of the sample period is roughly one-third the size of our sample at the end, but even for the first years, we have more than 5,000 observations. The sample size is smaller for our multivariate analysis, but the characteristics of the sample in terms of its sample size are similar.

\subsection{Definition of LTV ratios}

LTV ratios are defined as the ratio of the amount of a loan, either being extended or committed (maximum), to the current value of real estate being pledged as collateral. It represents the exposure of each lender, because if the value (V) decreases by 1-LTV percent, then the lender may suffer a loss given default if the debtor has a negative equity position.

To calculate the LTV ratios, information about the numerator $(\mathrm{L})$ is available from the TDB database as explained above. We calculate V, the denominator, by multiplying the acreage of the related land (also from the TDB database) by an estimated per-acreage price of the land. We estimate the land price using a hedonic model, an approach widely used in real estate economics. This approach assumes that the price of a parcel of land is the sum of the values of its attributes such as size, floor area ratio, physical distance to a metropolis in the region, etc. We start with the dataset Public Notice of Land Prices (PNLP) compiled by the Land Appraisal Committee of the Ministry of Land, Infrastructure, Transport and Tourism of the Government, and estimate a hedonic

these variables to the baseline specifications, the results (available upon request to the authors) are qualitatively unchanged from what we will reportin later sections. 
model in which the log price of land (taken from the PNLP) is a function of different explanatory variables. ${ }^{26}$ Using the parameter estimates from this estimation, we project (predict) the current price of each piece of land in our dataset based on its characteristics from the TDB database. ${ }^{27}$ For more details on the estimation of V, see Appendix A.

The calculation of the LTV ratio becomes more complicated when there are multiple loans and multiple lenders with different levels of priority. For example, even in a simpler case where there are multiple loans secured with the same land, the LTV ratios of junior loans need to take into account the amount of senior loans. We provide an illustrative explanation on how we calculate the LTV ratio in these and other cases in Appendix B.

Our LTV ratios based on registration information are origination LTV ratios, i.e., those based on the L and V at the time of loan origination. Using the origination LTV ratio is appropriate for two reasons. First, from a bank management point of view this is the relevant ratio in loan underwriting. Second, the policy debate principally relates to LTV caps imposed at the time of origination.

It is worth mentioning that although buildings are commonly pledged as collateral in Japan together with the land on which they are built, we have no information on the value of buildings, and so our analysis is confined to land value only. To some extent,

\footnotetext{
${ }^{26}$ The explanatory variables in this estimation are the log size of the land, the regulatory upper limit of the floor area ratio, the Euclidean distance of the land to the highest price piece of land in the same prefecture, the square term of the Euclidean distanœ, the Euclidean distanœe of the land to the highest price piece of land in the samecity, the square term of thedistanœ, thelatitude of the land and its square term, the longitude of the land and its square term, and dummy variables representing the type of land district (i.e., whether the land is located in a residential, commercial, or industrialized district). We run a regression for each combination of land district type (3 types: residential, commencial, or industrialized), year (35 years: from1975 to 2009), and region (either 47prefectures or 15 regional units), which resulted in thetotal of 3,813 estimated regressions.

${ }^{27}$ Wecannot directly use the PNLP because its soope is limited and it does not provide us with the prices for the particular pieces ofland that our sample firms pledge as collateral.
} 
this is not likely to be a serious problem because in practice bankers in Japan have historically put less emphasis on the value of buildings than land as collateral. This is because in Japan, the value of buildings depreciate relatively rapidly, presumably because the market for used buildings is not very liquid, and their durable years are much less than in Europe or the U.S. ${ }^{28}$ However, to control for any potential bias due to a lack of information on the market value of buildings, we will control in the regression analysis for the book value of the buildings (see below).

\section{Cyclicality of LTV ratios}

In this section, we address the primary focus of our paper - the efficacy of an unconditional LTV cap as a macro-prudential policy tool, by examining cyclical changes in LTV ratios and their determinants. Recall that a necessary condition for an unconditional LTV cap to be effective is the existence of pro-cyclical behavior in the LTV ratio. After providing some background information on Japanese aggregate business activity and Japan's land price bubble, we explore the evolution of LTV ratios over the Japanese business cycle in section 4.1. In section 4.2 we report the results from our multivariate analysis that controls for, among other things, survivorship bias.

\footnotetext{
${ }^{28}$ The Council for Social Infrastructure (2005) reports that in Japan, residential houses lose their physical integrity within 31 years on average, which is far shorter than 44 years in the U.S. and 75 years in the U.K. Regarding commencial property (e.g., office buildings), we don't have any specific evidenœe justifying this practice of devaluing buildings by bankers. However, it is likely that the depreciation of oommercial property in J apan relative to the rest of the world maps the relatively rapid depreciation of residential property in Japan.
} 


\subsection{LTV ratios over the business cycle: Univariate analysis}

\subsubsection{Background information: The business cycle and the bubble}

In order to provide some context for our analysis of the evolution of LTV ratios in Japan, we first take a brief look at the Japanese business cycle and the land prices using macro statistics. Figure 2 shows the time-series path of the real GDP, the average land price, and the stock of bank loans outstanding, and the so-called "bubble" period from late 1980s to early 1990s is shaded. The spike in land prices at the end of the bubble period is especially remarkable. During this period, real GDP grew at a faster pace than in the pre-bubble period, and the growth rates of land prices and bank loans were even higher than the rate of real GDP growth.

After the bubble burst, Japan encountered several expansions and recessions and real GDP grew at a substantially lower rate than in the bubble period. Bank loans exhibited a similar cyclical pattern, but they decreased on average rather than increased after the bubble burst. Land prices showed a steady decline over these twenty years, finishing with a price level comparable to that in the early 1980s.

\subsubsection{Cyclicality of loans, land values, and LTV ratios}

We begin our analysis by first examining separately the evolution of the numerator and the denominator of the LTV ratio, i.e., the amount of loans originated (L) and the estimated value of the collateralized land (V). We then turn to the evolution of the LTV ratio $(\mathrm{L} / \mathrm{V})$ itself. $^{29}$

Figure 3 shows the changes in the 25, 50, and 75 percentiles of our $\mathrm{L}$ and $\mathrm{V}$ through the business cycle. The respective pattems of the evolution of $\mathrm{L}$ and $\mathrm{V}$ are not

\footnotetext{
${ }^{29}$ Note that our L that is at the loan level is inevitably in flow terms, while the amount of loans outstanding that is at theaggregatelevel in Figure2 isin stockterms.
} 
particularly surprising - both are pro-cyclical. They each have an increasing trend until around 1991 when the asset price bubble burst in Japan, and a decreasing one until the mid-2000s. They go up afterwards, with the increase in the loan amount larger than the increase in the land value. These changes are on balance consistent with the findings using macro statistics in Figure 2, and the finding of pro-cyclical lending is consistent with the existing evidence (e.g., Borio et al. 2001, Berger and Udell 2004).

Now we tum to the LTV ratio, the key focus of our analysis. Figure 4 shows the LTV ratio by percentile (25th, 50th, and 75th percentile). Notwithstanding that its numerator and denominator fluctuate in a pro-cyclical manner, the LTV ratio clearly exhibits counter-cyclicality, at least until early in the 2000s when it disappears. Our finding is striking in the sense that it is inconsistent with conventional wisdom on lax lending standards during the bubble period in Japan. The counter-cyclicality of the LTV ratio until the early 2000s is not driven by the stickiness of the land prices because as shown above, V indeed exhibits pro-cyclicality. The fact that loans and land values are both pro-cyclical diminishes concern that the counter-cyclicality of the LTV ratio is just an artifact of data problems.

Although our focus is not on the absolute level of the LTV ratio, the observed median LTV being greater than one might seem surprising. However, as we noted above, we do not (cannot) include the market value of buildings which are also often pledged as collateral as well. We address this problem in our multivariate analysis below by including the book value of buildings (from firm balance sheets) as a control in our regressions.

Relatedly, we note that the lack of market values on buildings in the denominator of the LTV ratio will not likely change our main conclusion that LTV ratios are 
countercyclical. It is quite likely that the value of buildings will follow a pro-cyclical pattern similar to land values, and thus likely that they will be high (low) in the boom (bust) period, although they might be less pro-cyclical than land values. Therefore, even if we could include the value of buildings in the denominator, it would change the counter-cyclicality of LTV ratios only quantitatively (and not qualitatively).

\subsubsection{Discussion}

One possible concem in our analysis might be that the counter-cyclicality of the LTV ratio is driven by a survivorship bias inherent in our data. As noted above, our sample firms are those that survived until 2008 or afterwards, and so the LTV ratios in earlier years could be associated with longer-lived firms that are likely to be more creditworthy. However, if such a survivorship bias existed in our data, the LTV ratio should have a monotonically decreasing trend reflecting the change in the mix of firm quality over time: that is, for better-quality firms that dominate the earlier periods, banks would be willing to lend more for the same amount of collateral, ceteris paribus. This is not the case in Figure 4. Thus, to be problematic for our analysis the survivorship bias problem must be limited to the bubble period which seems unlikely. Our data do not allow us to directly rule out this possibility. However, subsequent analysis on ex post performance (Section 5.2) does confirm that among those loans that survived until 2008, high LTV borrowers exhibited better, not worse, performance than low LTV borrowers.

There might still be other forms of survivorship bias that might affect our findings in the other direction. For example, high quality firms might demand less credit because they have more internal resources, and thus tend to have low LTV loans. To account for any bias, we will include below a variety of controls for loan, borrower, and 
lender characteristics - and see if the counter-cyclicality observed in our univariate analysis still survives.

Another possible criticism of our methodology is that lenders might take into account expected future land values when underwriting loans, which makes it inappropriate to use as $\mathrm{V}$ the current value of land as we did above. To address this concem, we calculate and compare the LTV ratios under two different alternative definitions of $V$. The first definition is the land value evaluated one year later, $V(t+1)$, which benchmarks the case where lenders could perfectly foresee and underwrite their loans based on the value of land realized one year later ${ }^{30}$ The second definition uses a $\mathrm{V}$ that is interpolated from its previous year's growth rate, i.e., $\mathrm{V}(\mathrm{t}-1) \cdot\{\mathrm{V}(\mathrm{t}-1) / \mathrm{V}(\mathrm{t}-2)\}$, which assumes a naive prediction based on its past values. Under either of these alternative definitions of V the LTV ratios still exhibit almost similar counter-cyclicality as shown in Figure 4. Thus, our finding of counter-cyclical LTV ratios is robust to different assumptions about $\mathrm{V}^{31}$

Our finding of counter-cyclical LTV ratios is not entirely inconsistent with findings elsewhere. In fact, our finding is consistent with one of the conclusions in Goodhart et al. (2012). In a general equilibrium model, they calibrate the effects of different macro-prudential policy measures on credit expansion and house prices. Regarding LTV caps, they conclude that a large increase in asset prices in a boom lowers the LTV ratio making it difficult to "lean against the wind to reduce the credit expansion and house prices in the boom via regulation” (Goodhart et al. 2012, p.42).

\footnotetext{
${ }^{30}$ Using $\mathrm{V}(\mathrm{t}+1)$ might also be appropriate because there might be a lag in reporting the land price in the data that we used to predictland values (i.e., PNLP).

${ }^{31}$ SeeOno etal. (2013, subsection 3.13.) for theseresults.
} 
There is also empirical evidence that is consistent with our finding. In Japan, the Bank of Japan (2012, Chart IV-3-10) shows an increasing trend in the evolution of LTV ratios in the residential mortgage market during the period 1994 to 2009 . In the U.K., the FSA (2009, Exhibit 4.1) reports that average origination LTV ratios for home purchases generally fell from 1997 to the late 2000s, especially during the credit boom period. In the U.S., Justiniano et al. (2015, Figure 1.2.) find that residential mortgage LTVs remained unchanged during the housing boom until 2006, and then spiked after the collapse of housing prices. Campbell and Cocco (2014, Figure 1) report that origination LTV ratios for residential mortgages were stable from 1984-2008. Using U.S. data from 1998-2008 Glaeser et al. (2013, Table 7.13) report that cumulative origination LTVs ratios (using the sum of the loan amounts of up to three mortgages as the numerator) are fairly stable over time, but that origination LTV ratios for first lien residential mortgages are counter-cyclical. Although the markets (residential vs. business loans) and the variable definition (post-origination, at-origination or otherwise) are different, our findings are overall consistent with the findings in these papers. ${ }^{32}$

The counter-cyclicality of the LTV ratio means that bank risk exposure was decreasing, not increasing, during the bubble period in terms of current (real time) pricing (at least conditional on lenders lacking contemporaneous knowledge of being in a bubble period). This finding implies that banks in Japan did not take excessive risk during the bubble period and suggests that a simple cap on the LTV ratio as a macro-prudential measure may not have worked as a binding constraint on bank lending.

32 Note that the U.S. evidence is immune to survivorship bias because these studies either use aggregatedata (J ustiniano etal. 2015and Campbell and Cocoo 2014) or the universe of micro data (the89 U.S. metropolitan areasin Glaeser et al. 2013). 


\subsection{Cyclicality of LTV ratios: Multivariate analyses}

\subsubsection{Methodology and main variables}

In this section, we investigate whether the counter-cyclicality of LTV ratios found in section 4.1 still holds after controlling for a variety of factors. This control is important to address the potential survivorship bias that is inherent in our data because our data are synthetic in nature and because older data are associated with longer-lived borrowers (see section 3.1). To perfectly control for this bias, we would need data for non-survivors - which we do not have. However, we have rich information on loan, borrower, and lender characteristics, so we can examine the cyclicality of the LTV ratios after controlling for these characteristics. To the extent that counter-cyclicality disappears by this control, what we found in the previous section is an artifact of differences in the loan-, borrower-, and/or lender-characteristics in different years, part of which might stem from the survivorship bias. However, to the extent that it does not disappear, we can confirm that the LTV ratios are indeed counter-cyclical. Because the LTV ratios are one of the key contract terms set by lenders, this regression also indicates how lenders determine the ratios.

Table 1 shows variable definitions and summary statistics for the variables that we use in the multivariate analysis except for the registration year dummies that are summarized in Figure 1. Our dependent variable is the LTV ratio. The main independent variables of interest are the registration year dummies (YEAR1991-2009, with 1990 as the default). We also use our controls for loan, borrower (firm), and lender characteristics, some of which will be explained in subsection 4.2.2. We focus on whether the year dummies exhibit the same counter-cyclicality after controlling for all of these factors. 
Because LTV ratios measure risk exposure, it is intriguing to examine their determinants not only for average LTVs but also for relatively high or low LTV ratios. We thus run three quantile regressions rather than OLS regressions: median (50 percentile (p50)), 10 percentile (p10), and 90 percentile (p90) regressions. Focusing on median is better than focusing on mean because as Table 3 shows, the mean LTV ratio (7.7) is relatively higher than the median (1.4), suggesting that there are outliers with large LTV ratios. ${ }^{33}$

To deal with the simultaneity bias, we use the borrower and lender characteristics variables as of one year prior to the origination/registration of the loans. Data limitations regarding many of our independent variables preclude us from running, the regression from 1975, the initial year for which we can calculate LTV ratios. All of our variables are available beginning in 1989. In order to take one year lags, our sample period for the regression analyses begins in 1990 and ends in 2009.

\subsubsection{Loan characteristics}

Our first control for loan characteristics is a dummy variable for ne-tanpo (L_netanpo). As explained in section 3.1, we have two types of collateral in our data set: ordinary one and ne-tanpo. Ne-tanpo allows banks to take collateral in anticipation of loans that might be committed to in the future. Table 1 shows that $66 \%$ of our sample loans are ne-tanpo loans. Because loans secured by ne-tanpo are usually used to raise working capital, $L \_$netanpo is a proxy for short maturity. Both positive and negative signs are expected on this variable depending on the term structure of interest rates and the riskiness of borrowers to which banks demand ne-tanpo.

${ }^{3}$ When we run OLS regressions after dropping observations that fall in $1 \%$ tails of the LTV distribution, the results (not reported) are qualitatively the sameas those of the median regression below. 
We also use four dummy variables to capture loan priority $\left(L \_P R 1-4\right.$, the default case is the fifth or lower priority). Because the payoff sensitivity of junior loans (like second mortgage home equity loans in the U.S) to changes in the value of the underlying real estate is greater than the sensitivity of senior loans, LTV ratios may be different for these loans controlling for risk and assuming comparable demand. In Table 1, we not surprisingly find more senior loans than junior ones in our sample.

\subsubsection{Firm characteristics}

Our firm controls are the natural logarithm of sales (F_lnSALES), profitability (ROA: the ratio of operating profit to total asset), the capital-asset ratio $\left(F \_C A P\right)$, and firm age (F_AGE), which proxy for firm risk, performance and transparency. We also expect that these variables control for the potential survivorship bias in our data.

We also include the ratio of buildings to total assets (F_BUILD), based on the balance sheet information to address the possible bias stemming from the non-availability of the market value of buildings in the denominator of the LTV ratio. In the presence of such a bias, $F \_B U I L D$ is expected to have a positive coefficient.

Finally, to control for region- and industry-specific factors that might affect LTV ratios, we use nine regional dummies (F_REG1-9, Hokkaido/Tohoku is the default (= F_REG0)), and seven industry dummies (F_IND1-7, other industries is the default $\left.\left(=F \_I N D 0\right)\right)$.

\subsubsection{Lender characteristics}

Lender controls include a dummy variable for whether the lender is the main bank (BK_MAIN), defined as the lender listed at the top of TDB's list of lenders that the firm 
transacts with. ${ }^{34}$ Because main banks are generally considered to take more credit risk than non-main lenders, we expect a positive coefficient on BK_MAIN.

We also use six lender type variables. ${ }^{35}$ Regional banks (including second-tier regional bank), indicated by BK_TYPE1, are middle-sized regional lenders that operate in a specific region. Shinkin banks (BK_TYPE2) and credit cooperatives (BK_TYPE3) are small cooperative financial institutions that operate in yet smaller regions. For some sample firms their main bank is a government-affiliated financial institution, which is indicated by BK_TYPE4. BK_TYPE5 indicate other banks, security companies, or insurance companies, and BK_TYPE6 indicate that the lender is other than these financial institutions (i.e., non-banks, credit guarantee corporations, non-financial firms, etc.). The default is city banks (BK_TYPE0: not used in the regression), the largest banks in Japan by size, all of whom operate nationwide. These variables help control for any risk appetite that might vary by bank type.

\subsubsection{Policy variables}

In addition to loan-, borrower-, and lender-characteristics, we add dummy variables to control for two policy initiatives that might affect the level of LTV ratios. The first is a policy measure that placed a ceiling for all banks on the aggregate amount of loans to real estate firms. The Ministry of Finance introduced the ceiling in 1990 to curb the booming lending to real estate firms and removed it in 1991 (Uemura 2012). We use a dummy, PL_CEILING, that takes a value of one if the registration year is either 1990 or 1991 and the borrower is a real estate firm. We expect that this variable to have a negative coefficient.

${ }^{34}$ Thebanks on the list are ordered based on theirimportanceas subjectively determined by TDB.

${ }^{35}$ SeeUchidaand Udell (2014) for banktypesin Japan. 
The second initiative is the 2003 Action Program on Relationship Banking imposed by the Financial Services Agency (FSA) in Japan, through which the FSA requested that regional banks, Shinkin banks, and credit cooperatives avoid an “excessive” reliance on collateral and personal guarantees when extending loans to SMEs. The dummy variable $P L \_A C T I O N$ takes a value of one if the registration year is 2004 or later, and if the lender type is one of the above three. To the extent that banks responded positively to the request and became more willing to lend without taking collateral, we expect a positive coefficient on PL_ACTION.

\subsubsection{Results}

Table 2 shows the regression results. Column (A) reports our baseline results using the median (50 percentile) regression, and Columns (B) and (C) report the results for the quantile regressions at the 10 percentile (for lower LTV ratios) and 90 percentile (for higher LTV ratios). At first glance, we can confirm that in each column, most of the variables are significant and reflect their expected signs.

The key finding here is that the year dummies in each column consistently exhibit an increasing trend in the LTV ratios from 1993 or 1994 to 2009 (as compared to 1990). This means that the LTV ratios in the midst of, or just after, the bubble period were low compared with those afterwards. This finding is consistent with the counter-cyclical LTV ratio that we found in our univariate analysis (Figure 4). We note that our multivariate results now control for a variety of factors that might also affect the LTV ratio and that also control for potential survivorship bias. Irrespective of observable loan, firm, and lender characteristics, banks in Japan during the bubble period did not lend more aggressively (in terms of their risk exposure as measured by LTV ratios). Rather, the increase in the value of collateral during the boom was more than offset by the 
increase in the loan amount. Again, this finding casts doubt on the effectiveness of a simple LTV cap as a macro-prudential tool.

If we compare the results for different percentiles, we find that the coefficients for the year dummies are smaller in the smaller percentile regressions. This finding suggests that the magnitude of the counter-cyclicality of LTV ratios is modest for lower LTV ratio loans, while it is amplified for higher LTV ratio loans. Because regulatory caps on LTV ratios target higher LTV ratios, our finding that 90 percentile of LTV ratios are more counter-cyclical strengthens our doubt on the effectiveness of simple LTV caps. However, alternatively larger coefficients for the year dummies in the 90 percentile regression might just be an artifact of higher absolute values for high LTV ratios.

We also ran quantile regressions on just “ordinary” loans as opposed to ne-tanpo loans. These regressions provide information on two dimensions. First, this will indicate whether our main multivariate results are specific to the type of loan. And, second, it will shed a bit of light on the issue of LTV caps on loans that are used to purchase real estate. Although our data do not include information on the purpose of the loan, it is highly likely (as explained earlier) that ne-tanpo loans are used for financing working capital, and so secured business loans used to purchase the underlying (associated) real estate would be confined to "ordinary" loans. Thus, the regression focusing only on ordinary loans can produce purer, although indirect, information on LTV ratios of loans for which the pricing channel might be relevant in addition to the risk channel (see section 2.1 for the two channels). However, we find that the results in these regressions (not reported) do not differ qualitatively from our reported regressions, except for some large coefficients in the 90 percentile regressions. 


\section{LTV ratios and the ex post performance of borrowers}

\subsection{Methodology}

In this section, we examine the relationship between the level of the LTV ratio and the ex post performance of the borrowers. The purpose of this analysis is to examine the validity of one of the main arguments made by proponents of LTV caps: high-LTV loans perform worse than low-LTV loans (see, for example, FSB 2012). If this is the case, imposing an LTV cap would inflict little or no harm while minimizing bank losses by constraining loans to poorly performing borrowers. While some evidence on the ex-post performance of high LTV loans justifies this assertion for residential mortgages, there is little evidence on business loans. ${ }^{36}$

Our analysis is conducted in the spirit of a difference-in-differences (DID) approach. We construct a sample of treatment observations (high-LTV borrowers) and a sample of control observations (low-LTV borrowers). Then we compare the ex post performance of these two groups using several altemative performance measures. Due to data availability, we examine the ex post performance of borrowers, not their loans. ${ }^{37}$

We define our treatment (high-LTV) observations as firms whose loans are in the fourth quartile of the entire sample in terms of their LTV ratios. The control observations are defined using two altemative procedures. First, we simply consider all non-treatment firms (non-high-LTV loans) as the control observations. Second, we choose as non-treatment firms those firms that have similar ex-ante characteristics with

${ }^{36}$ For the reoent evidence on the positive relation between origination LTV ratios and default rates for residential mortgages, see, for example, Campbell and Coooo (2014) and FSA (2009) and referenoes therein. As far as we know, Agarwal and Ben-David (2014) is the only paper that examines the effect of LTV ratios on loan performanoe for business loans, although it is not the main focus of thepaper.

${ }^{37}$ In the case where a firm obtained multiple secured loans in a year, we use the one with the highest LTV ratio. Thenumber of observations is thus reduced from 59,125loans in the previous section to 48,334 firms for this analysis. 
each treatment firm by employing a propensity score matching approach. To calculate the propensity scores, we run a probit regression that models the probability that a borrower obtains a high-LTV loan conditional on the covariates that are used in section 4.2. ${ }^{38}$ For each treatment (high-LTV) observation, the matched observation is selected from the non-treatment firms by having the closest propensity score. ${ }^{39}$

Using matched controls allows us to control for the differences in ex-post performance between high- versus low-LTV firms stem from differences in ex-ante characteristics. $^{40}$ Matched controls also eliminate, at least partially, the survivorship bias that a simple unmatched control group might suffer from. However, because simple (uniform) caps on LTV ratios in practice are unconditional, we also use unmatched controls.

Between treatment and control groups, we analyze the DID of several performance variables. For each treatment or control firm, we take differences in its performance variables from year $t$ (when the loan was originated) to year $t+k$ ( $k=1$ to 5 ). This eliminates time-invariant firm-fixed effects. We then calculate the average difference in these differences within the treatment and control firms (either unmatched or matched). We use as performance variables (1) the number of employees and (2) the $\log$ amount of sales to represent firm growth (in terms of size), (3) ROA to represent changes in firm profitability, and (4) the capital-asset ratio to represent changes in credit risk. As in the quantile regressions in the previous section, the sample period begins in

38 The results of the probit estimation are similar to those of the quantile regressions in Table 4 , and so we do notreport them (which are availablefrom theauthors).

${ }^{39}$ There are several matching algonithm to find the dosest control observations. We employ 5-nearest matching, in which 5 observations whose propensity soores are the closest to each treatmentobservation are chosen.

40 Following studies that employ propensity score matching DID approach, we assume unconfoundedness, i.e., thetreatment/ ontrol choiceisindependent of the outoome. Ourrich set of covariates employed for the propensity soorematchingjustifies this assumption. 
1990 due to data availability. Because we take five year differences at maximum in the performance variables, the sample period ends in 2004.

\section{2. $\quad$ Results}

Table 3 shows the results of the ex-post performance analysis in the case of the unmatched DID estimator (Panel (1)) and in the case of the propensity score matching DID (PSM-DID) estimator (Panel (2)). In each panel, column (A) reports the estimation results using the whole sample, while columns (B), (C), and (D) respectively report those using subsamples of 1990-94, 95-99, and 2000-04. In each column, we show the average ex-post performance of treatment groups (high LTV firms) and control groups (non-high LTV firms) in terms of their differences between year $t$ and $t+k(k=1$, $2, \ldots, 5)$. The difference-in-differences of the performance variables between these two groups and corresponding standard errors are also shown, together with the results of hypothesis testing, where the null hypothesis is that the average performance of the treatment groups and the control groups are the same.

Looking first at the unmatched DID estimator (Panel (1)), the whole sample results in column (A) show that treatment firms (high LTV firms) perform better than control firms (low LTV firms) in terms of employment growth (d_F_EMP in years $\mathrm{t}+1$ and $\mathrm{t}+2$ ) and in terms of changes in profitability $\left(d \_F \_R O A\right.$ in years $t+3, t+4$, and $\left.t+5\right)$. We find no significant differences between these two groups in terms of sales growth (d_F_lnSALES) and changes in the capital-asset ratios (d_F_CAP). Also, significant and positive DID estimators for $d \_F \_E M P, d \_F \_l n S A L E S$, and $d \_F \_R O A$ in column (B) show that the high LTV borrowers perform better especially in years 1990-94 (during and after the bubble burst). However, as shown in columns (C) and (D), after the 
bubble burst, we no longer find that treatment firms performed better. They sometimes exhibit worse performance (e.g., negative DID estimators for $d \_F \_I n S A L E S$ ).

Turning to the matched-DID estimators shown in Panel (2), from column (A) using the whole sample, we find that high LTV firms performed better in terms of employment growth. However, we find no significant differences in other ex-post performance variables. These findings suggest that the performances of high LTV borrowers and the performance of low LTV borrowers with similar ex-ante characteristics are almost comparable. Looking at columns (B), (C) and (D), we observe that the average performance of treatment firms was better during 1990-94, but the differences almost disappeared afterwards.

To summarize, we find that the ex-post performance of firms with higher LTV loans was not worse, and actually better, during or just after the bubble period. These findings suggest that a high LTV ratio does not reflect by itself lax lending standards in the sense that firms that obtained these loans did not perform poorly afterwards.

As in our analysis of the cyclicality of LTV ratios, survivorship bias might be a concern with respect to our findings on the observed superior ex-post performance of high LTV borrowers, i.e., this finding might just reflect the fact that only high LTV borrowers with better-quality survived until 2008. However, to the extent that the survivorship bias affects both high and low LTV borrowers our conclusions would still hold.

What could explain our finding that the ex-post performance of high LTV firms is no worse given that high LTV loans expose lenders ceteris paribus to more risk? One possible interpretation (as we noted above in our discussion of LTV countercyclicality) is 
that lenders tend to extend high LTV loans only to firms whom they have identified as high quality in their loan underwriting.

Our findings of no worse ex-post performance, and even better performance after the bubble, for high LTV borrowers would seem to be inconsistent with the findings on zombie firms (e.g., Peek and Rosengren 2005, Caballero, Hoshi, and Kashyap 2008). However, we need to keep in mind that what these studies find is evidence suggesting that poor-performing firms could survive due to evergreening loans by banks, which cannot be directly compared with our findings for ex-post performance of high versus low LTV borrowers. Also, these studies focus mostly on late 1990s, but we find the better ex-post performance for early 1990s.

The finding of non-worse ex post performance for high LTV loans has an important policy implication. In the previous section, we find evidence suggesting that a simple cap on the LTV ratio on business loans would have been ineffective in dampening lending booms in Japan. In addition to this ineffectiveness, the finding in this section implies that imposing a simple LTV cap might have curbed lending to growing firms.

\section{Conclusion}

Using unique data from the official real estate registry in Japan, this paper looks at the LTV ratios of business loans secured by real estate in order to draw some implications for the ongoing debate on the use of LTV ratio caps as a macro-prudential policy measure. We find that, although the amount of loans and the value of land pledged as collateral are individually pro-cyclical, their ratio, i.e., the LTV ratio, exhibits counter-cyclicality. This finding is robust to controlling for various loan-, borrower-, and 
lender-characteristics, and to controlling for survivorship bias. We also find that, ex post, borrowers that were granted loans with high LTV ratios did not perform poorly compared with those granted low LTV loans.

Our findings have important policy implications. Caps on LTV ratios are a pressing topic of debate among policymakers. Proponents argue that curbing high LTV loans would enable us to reduce bank risk. Our findings do not support this view. First, our finding that the LTV ratio exhibits counter-cyclicality suggests that a simple cap would not be binding and would fail to dampen the build-up of risk in the banking system during the boom period. The finding also suggests that if we want to curb the volume of credit during the boom, we might need have a very low LTV cap. Second, the finding of no-worse (even better) ex post performance of high-LTV borrowers suggests that a simple LTV may counter-productively constrain well-performing borrowers. Our findings also imply that the efficacy of an LTV cap may depend crucially on how it is conditioned.

While our analysis focuses on business lending, our results on LTV pro-cyclicality and no-worse LTV loan performance could conceivably apply to residential mortgages as well. However, two caveats are worth mentioning in generalizing our findings to the analysis on LTV caps on mortgages. First, inconsistent with the results from our ex post performance analysis, high LTV lending in the U.S. residential mortgage market in the form of subprime mortgages appears to have resulted in higher losses. Second, first (i.e., senior) residential mortgages are usually used to purchase the real estate itself, unlike most secured business loans in our sample. To examine LTV ratios of mortgages, we need to take into account their direct link with asset pricing (the pricing channel). However, it should also be noted that the pricing channel is not likely to have worked for 
home equity lines of credit (HELOCs) in the U.S., many of which were used for purposes other than purchasing or improving existing real estate.

\section{References}

Agarwal, S., and I. Ben-David, (2014). Do Loan Officers’ Incentives Lead to Lax Lending Standards? NBER Working Paper No. 19945.

Aiyar, S., C.W. Calomiris, and T. Wieladek. (2014). Does Macro-Prudential Regulation Leak? Evidence from a UK Policy Experiment, Journal of Money, Credit, and Banking 46, 181-214.

Almeida, C., M. Campello, and C. Liu. (2006). The Financial Accelerator: Evidence from International Housing Markets, Review of Finance 10, 321-352.

Bank of Japan. (2012). Financial System Report. October.

Barlevy, G and J.D.M. Fisher, (2012). Mortgage Choices and Housing Speculation, mimeo.

Basten, C., and C. Koch. (2014). Higher Bank Capital Requirements and Mortgage Pricing: Evidence from the Countercyclical Capital Buffer (CCB). Working paper.

Beck, T., A. Demirgüç-Kunt, and M. S. Martinez Peria. (2008). Bank Financing for SMEs around the World: Drivers, Obstacles, Business Models, and Lending Practices, World Bank Policy Research Working Paper Series No. 4785.

Berger, A.N., and GF. Udell. (2004). The Institutional Memory Hypothesis and the Procyclicality of Bank Lending Behavior, Journal of Financial Intermediation 13, 458-495.

Berger, A.N., and GF. Udell. (2006). A More Complete Conceptual Framework for SME Finance, Journal of Banking and Finance 30, 2945-2966. 
Borio, C., Furfine, C., and P. Lowe. (2001). Procyclicality of the Financial System and Financial Stability: Issues and Policy Options, Bank for International Settlements.

Caballero, R.J., T. Hoshi, and A.K. Kashyap, (2008). Zombie Lending and Depressed Restructuring in Japan, American Economic Review 98, 1943-77.

Campbell J. Y., and J. F. Cocco, (2014). A Model of Mortgage Default, Journal of Finance, forthcoming.

CGFS (Committee on the Global Financial System). (2010). Macroprudential Instruments and Frameworks: a Stocktaking of Issues and Experiences, CGFS Papers No 38, Bank for International Settlements.

CGFS. (2012). Operationalising the Selection and Application of Macroprudential Instruments, CGFS Papers No 48, Bank for International Settlements.

Council of Land Policy, the National Land Agency, the Government of Japan. (1990). Report: How the Land Policy in the Future Ought to be Based on the Basic Act for Land, October 29. (in Japanese)

Council for Social Infrastructure, the Ministry of Land, Infrastructure, Transport and Tourism, the Government of Japan. (2005). Reference for the Report "On the Institutional Framework to Accommodate New Housing Policy.” (in Japanese)

Crowe, C., G Dell'Ariccia, D. Igan and P. Rabanal. (2013). How to Deal with Real Estate Booms: Lessons from Country Experiences, Journal of Financial Stability 9, 300-319.

FSA (Financial Services Authority, U.K.). (2009). Mortgage Market Review, FSA Discussion Paper 09/3.

FSB (Financial Stability Board). (2011). Thematic Review on Mortgage Underwriting and Origination Practices: Peer Review Report. 17 March. 
FSB. (2012). Principles for Sound Residential Mortgage Underwriting Practices, 18 April.

Gerlach, S., and W. Peng. (2005). Bank Lending and Property Prices in Hong Kong, Journal of Banking and Finance 29, 461-481.

Glaeser, E., J. D. Gottlieb, and J. Gyourko (2013), Can Cheap Credit Explain the Housing Boom? in E. L. Glaeser and T. Sinai eds., Housing and the Financial Crisis, Chapter 7, University of Chicago Press, pp. 301-359

Goodhart, C. A. E., A. K. Kashyap, D. P. Tsomocos, and A. P. Vardoulakis. (2012). Financial Regulation in General Equilibrium, NBER Working Paper No. 17909. Iacoviello, M. (2005). House Prices, Borrowing Constraints, and Monetary Policy in the Business Cycle, American Economic Review 95, 739-764.

Igan, D., and H. Kang. (2011). Do Loan-to-Value and Debt-to-Income Limits Work? Evidence from Korea, IMF Working Paper.

Illueca, M., L. Norden, and G.F. Udell. (2014). Do Changes in the Timeliness of Loan Loss Recognition Affect Bank Risk Taking? Working paper.

Justiniano, A., GE. Primiceri, and A. Tambalotti. (2015). Household Leveraging and Deleveraging, Review of Economic Dynamics 18, 3-20.

Kashyap, A., and J. Stein. (2004). Cyclical Implications of the Basel-II Capital Standards, Federal Reserve Bank of Chicago, Economic Perspectives 28, 18-31.

Kuttner, K.N. and I. Shim. (2013) Can Non-Interest Rate Policies Stabilize Housing Markets? Evidence from a Panel of 57 Countries, NBER Working Paper No. 19723.

Lamont, O.A. and J.C. Stein. (1999). Leverage and House-Price Dynamics in U.S. Cities, Rand Journal of Economics 30, 498-514. 
Laufer, S. (2014). Equity Extraction and Mortgage Default, paper presented at the $50^{\text {th }}$ Bank Structure and Competition Conference.

Lim, C., F. Columba, A. Costa, P. Kongsamut, A. Otani, M. Saiyad, T. Wezel, and X. Wu. (2011). Macroprudential Policy: What Instruments and How to Use Them? IMF Working Paper 11/23.

Maddaloni, A., and J. Peydró. (2013). Monetary Policy, Macroprudential Policy and Banking Stability: Evidence from the Euro Area, ECB Working Paper No. 1560.

Ohnishi, T., T. Mizuno, C. Shimizu, and T. Watanabe (2011). The Evolution of House Price Distribution, RIETI Working Paper Series 11-E-019

Ono, A., H. Uchida, S. Kozuka, and M. Hazama. (2015). A New Look at Bank-Firm Relationships and the Use of Collateral in Japan: Evidence from Teikoku Databank Data, in T. Watanabe, I. Uesugi, and A. Ono eds., The Economics of Interfirm Networks, ch.12, Springer.

Ono, A., H. Uchida, G. Udell, and I. Uesugi. (2013). Lending Procyclicality and Macroprudential Policy: Evidence from Japanese LTV Ratios, Available at SSRN: http://ssrn.com/abstract $=2262575$.

Peek, J., and E.S. Rosengren. (2005). Unnatural Selection: Perverse Incentives and the Misallocation of Credit in Japan, American Economic Review 95, 1144-66.

Petersen, M. A., and R. G Rajan. (2002). Does Distance Still Matter? The Information Revolution in Small Business Lending, Journal of Finance LVII, 2533-2570.

Quint, D. and P. Rabanal. (2014). Monetary and Macroprudential Policy in an Estimated DSGE Model of the Euro Area, International Journal of Central Banking 10, 169-236.

Stein, J. (1995). Prices and Trading Volume in the Housing Market: A Model with Down 
Payment Effects, Quarterly Journal of Economics 110, 379-406.

Svensson, L. E. (2012). Comment on Michael Woodford, 'Inflation Targeting and Financial Stability,' Sveriges Riksbank Economic Review, 2012:1.

Uchida, H., and G Udell. (20140). Banking in Japan, in A. Berger, P. Molyneux, and J. Wilson eds., Oxford Handbook of Banking ( $2^{\text {nd }}$ edition), Ch. 36, Oxford University Press.

Ueda, K. (2000). Causes of Japan's Banking Problems in the 1990s, in T. Hoshi and H. Patrick (eds.), Crisis and Change in the Japanese Financial System, Boston: Kluwer Academic Publishers.

Uemura, S. (2012). Japan's Experience with Credit Ceilings for Real Estate Lending, RIETI policy discussion paper 12-P-019 (in Japanese).

Vandenbussche, J., U. Vogel, and E. Detragiache. (2013). Macroprudential Policies and Housing Prices - A New Database and Empirical Evidence for Central, Eastern, and Southeastern Europe, mimeo. IMF and Bundesbank.

Yoshida, K. (1994). Faults of Japanese Bank Management, Toyo-Keizai Inc., Tokyo (in Japanese). 


\section{Tables and Figures}

\section{Figure 1 Number of Observations}

This figure reports the numbers of observations (NOB) in each year that are used for our univariate and regression analyses.

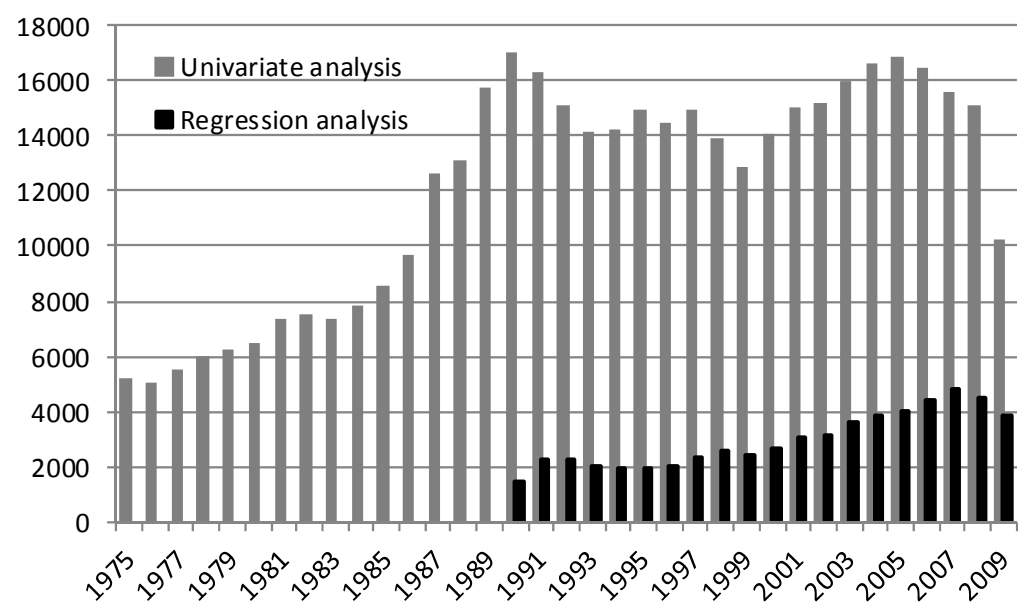

Figure 2 GDP, land price, and bank loans (2005 = 100)

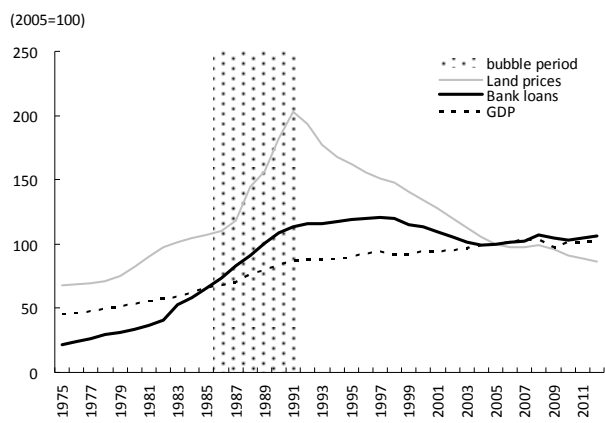

Source: Cabinet Office, "National Accounts," Land Appraisal Committee of the Ministry of Land, Infrastructure, Transport and Tourism, "Land Market Value Publication," Bank of Japan, "Financial and Economic Statistics" 
Figure 3 Loans and values over the business cycle

(A) Amount of loans (L) (in million Japanese yen)

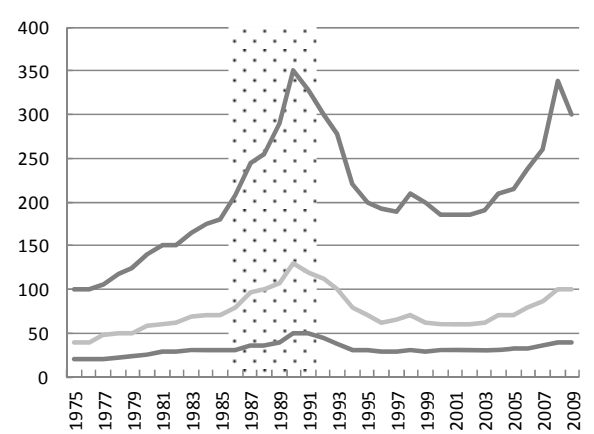

(B) Values of collateralized land (V) (in million Japanese yen)

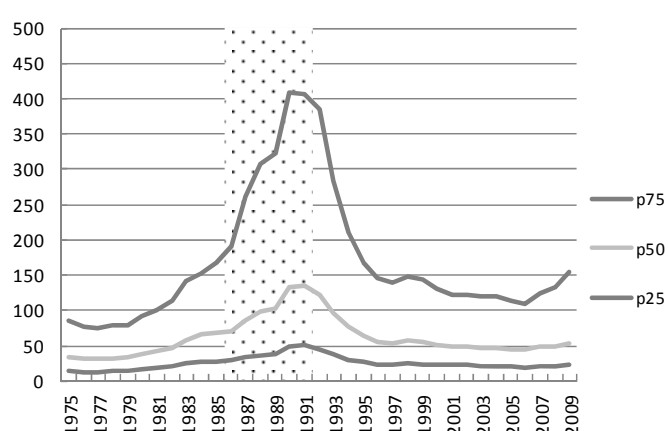

Figure 4 LTV ratios over the business cycle

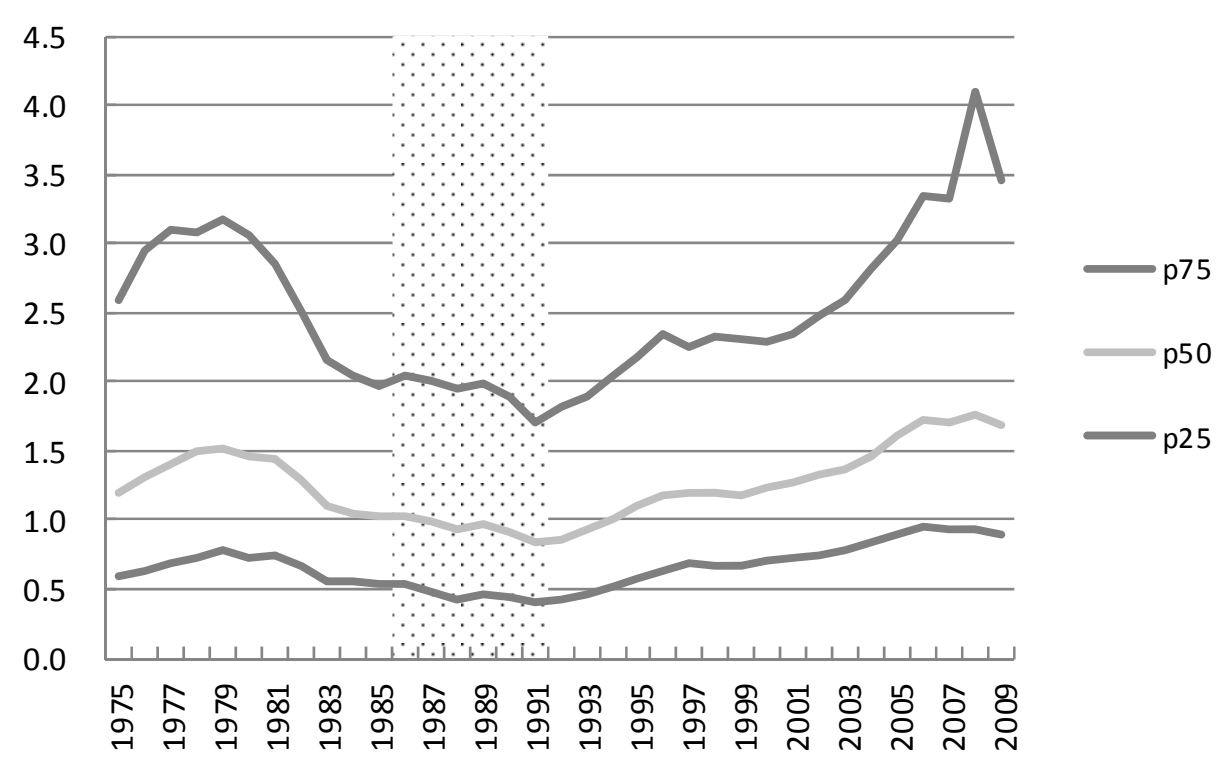


Table 1 Variable definitions and summary statistics

This table shows definitions and summary statistics of the variables used in the main analysis except for the year dummies. The number of observations is 59,125.

\begin{tabular}{|c|c|c|c|c|c|c|}
\hline & Definition & mean & sd & min & p50 & max \\
\hline \multicolumn{7}{|l|}{ Dependent variable } \\
\hline LTV & Loan-to-value ratio & 7.718 & 434.321 & 0.000 & 1.385 & 99681.800 \\
\hline \multicolumn{7}{|l|}{ Loan characteristics } \\
\hline L_netanpo & Ne-tanpo dummy: $=1$ if the collateral is ne-tanpo & 0.660 & 0.474 & 0 & 1 & 1 \\
\hline \multicolumn{7}{|c|}{ Loan priority dummies } \\
\hline$L \_P R O$ & Fifth or lower priority (default) & 0.070 & 0.255 & 0 & 0 & 1 \\
\hline$L \_P R 1$ & First priority & 0.586 & 0.492 & 0 & 1 & 1 \\
\hline$L \_P R 2$ & Second priority & 0.219 & 0.413 & 0 & 0 & 1 \\
\hline$L \_P R 3$ & Third priority & 0.085 & 0.278 & 0 & 0 & 1 \\
\hline$L \_P R 4$ & Fourth priority & 0.040 & 0.197 & 0 & 0 & 1 \\
\hline \multicolumn{7}{|l|}{ Firm characte ristics } \\
\hline F_lnSALES & Log of gross annual sales & 13.924 & 1.296 & 0 & 13.904 & 21.915 \\
\hline$F_{-} R O A$ & Return on Asset: = operating profit / total asset & 0.032 & 0.084 & -6.457 & 0.027 & 2.429 \\
\hline F_CAP & Capital-asset ratio: $=$ net worth $/$ total asset & 0.181 & 0.257 & -13.801 & 0.155 & 0.999 \\
\hline F_BUILD & Building-asset ratio: = building / total asset & 0.288 & 0.268 & 0 & 0.246 & 9.942 \\
\hline$F \_A G E$ & Firm age & 29.769 & 15.753 & 1 & 29 & 119 \\
\hline \multicolumn{7}{|c|}{ Borrower industry dummies } \\
\hline F_INDO & Other industries (default) & 0.003 & 0.057 & 0 & 0 & 1 \\
\hline F_IND1 & Construction & 0.317 & 0.465 & 0 & 0 & 1 \\
\hline F_IND2 & Manufacturing & 0.212 & 0.409 & 0 & 0 & 1 \\
\hline F_IND3 & Wholesale & 0.252 & 0.434 & 0 & 0 & 1 \\
\hline F_IND4 & Retail and restaurant & 0.052 & 0.222 & 0 & 0 & 1 \\
\hline F_IND5 & Real estate & 0.051 & 0.220 & 0 & 0 & 1 \\
\hline F_IND6 & Transportation and communication & 0.032 & 0.176 & 0 & 0 & 1 \\
\hline F_IND7 & Services & 0.080 & 0.272 & 0 & 0 & 1 \\
\hline \multicolumn{7}{|c|}{ Borrower regional dummies } \\
\hline$F \_R E G 0$ & Hokkaido and Tohoku (default) & 0.133 & 0.340 & 0 & 0 & 1 \\
\hline$F \_R E G 1$ & North Kanto & 0.030 & 0.170 & 0 & 0 & 1 \\
\hline$F \_R E G 2$ & South Kanto & 0.298 & 0.458 & 0 & 0 & 1 \\
\hline F_REG3 & Koshin-etsu & 0.070 & 0.255 & 0 & 0 & 1 \\
\hline$F \_R E G 4$ & Tokai & 0.106 & 0.307 & 0 & 0 & 1 \\
\hline F_REG5 & Keihanshin & 0.164 & 0.371 & 0 & 0 & 1 \\
\hline$F \_R E G 6$ & Other kinki & 0.015 & 0.120 & 0 & 0 & 1 \\
\hline F_REG7 & Chugoku & 0.067 & 0.250 & 0 & 0 & 1 \\
\hline$F \_R E G 8$ & Shikoku & 0.026 & 0.158 & 0 & 0 & 1 \\
\hline F_REG9 & Kyushu and Okinawa & 0.092 & 0.289 & 0 & 0 & 1 \\
\hline \multicolumn{7}{|l|}{ Lender characte ristics } \\
\hline BK_MAIN & $\begin{array}{l}\text { Main bank dummy: = } 1 \text { if the lender is a main bank (top- } \\
\text { listed bank) of a borrower firm. }\end{array}$ & 0.269 & 0.443 & 0 & 0 & 1 \\
\hline \multicolumn{7}{|c|}{ Lender type dummies } \\
\hline BK_TYPEO & City banks (default) & 0.146 & 0.353 & 0 & 0 & 1 \\
\hline BK_TYPE1 & Regional or second-tier regional banks & 0.296 & 0.456 & 0 & 0 & 1 \\
\hline BK_TYPE2 & Shinkin banks & 0.153 & 0.360 & 0 & 0 & 1 \\
\hline BK_TYPE3 & Credit cooperatives & 0.016 & 0.126 & 0 & 0 & 1 \\
\hline BK_TYPE4 & Government-affiliated financial institutions & 0.174 & 0.379 & 0 & 0 & 1 \\
\hline BK_TYPE5 & $\begin{array}{l}\text { Other banks, security companies, or insurance } \\
\text { companies, etc. }\end{array}$ & 0.013 & 0.112 & 0 & 0 & 1 \\
\hline BK_TYPE6 & $\begin{array}{l}\text { Others (non-banks, credit guarantee corporations, non- } \\
\text { financial firms, etc.) }\end{array}$ & 0.202 & 0.402 & 0 & 0 & 1 \\
\hline \multicolumn{7}{|l|}{ Policy measures } \\
\hline$P L \_A C T I O N$ & $\begin{array}{l}\text { FSA's action program dummy: = } 1 \text { if a lender is subject } \\
\text { to the FSA's Action Program on Relationship Banking } \\
\text { (YEAR is } 2004 \text { or afterwards and the lender type is } \\
\text { either 1, 2, or 3). }\end{array}$ & 0.222 & 0.415 & 0 & 0 & 1 \\
\hline PL_CEILING & $\begin{array}{l}\text { Dummy representing the MOF's ceiling policy to real } \\
\text { estate firms: }=1 \text { if the registration year is either } 1990 \text { or } \\
1991 \text { and the borrower is a real estate firm. }\end{array}$ & 0.001 & 0.035 & 0 & 0 & 1 \\
\hline
\end{tabular}




\section{Table 2 Estimation results - Quantile regressions}

This table presents the results for the analysis on counter-cyclicality of the LTV ratios by controlling for a variety of factors. The quintile regression results are shown, in which the dependent variables are the LTV ratios (LTV). Columns (A) through (C) respectively report the results at the 50 (median), the 10 , and the 90 percentile points of the LTV ratios. The main independent variables are the year dummies (YEAR1991-2009). For the definitions of the other variables, see Table 1. ***, **, and * respectively indicate that the relevant coefficients are statistically significant at the 1,5 , and $10 \%$ level.

\begin{tabular}{|c|c|c|c|c|c|c|c|c|c|}
\hline \multirow{2}{*}{$\begin{array}{l}\text { Estimation method: Quantile } \\
\text { regression } \\
\text { Dependent variable: } L T V\end{array}$} & \multicolumn{3}{|c|}{ (A) Median (p50) } & \multicolumn{3}{|l|}{ (B) $\mathrm{p} 10$} & \multicolumn{3}{|l|}{ (C) p90 } \\
\hline & \multicolumn{2}{|l|}{ Coef. } & Std. Err & \multicolumn{2}{|l|}{ Coef. } & \multirow[t]{2}{*}{ Std. Err } & \multicolumn{2}{|l|}{ Coef. } & \multirow[t]{2}{*}{ Std. Err } \\
\hline Registration year & & & & & & & & & \\
\hline YEAR1991 & -0.017 & & $(0.044)$ & -0.052 & $* *$ & $(0.025)$ & -0.051 & & $(0.226)$ \\
\hline YEAR1992 & 0.000 & & $(0.044)$ & -0.030 & & $(0.025)$ & -0.147 & & $(0.227)$ \\
\hline YEAR1993 & 0.074 & $*$ & $(0.045)$ & -0.005 & & $(0.025)$ & 0.016 & & $(0.231)$ \\
\hline YEAR1994 & 0.223 & $* * *$ & $(0.046)$ & 0.064 & $* *$ & $(0.026)$ & 0.611 & $* * *$ & $(0.236)$ \\
\hline YEAR1995 & 0.412 & $* * *$ & $(0.046)$ & 0.148 & $* * *$ & $(0.026)$ & 0.807 & $* * *$ & $(0.235)$ \\
\hline YEAR1996 & 0.545 & $* * *$ & $(0.045)$ & 0.209 & $* * *$ & $(0.026)$ & 0.928 & $* * *$ & $(0.234)$ \\
\hline YEAR1997 & 0.463 & $* * *$ & $(0.044)$ & 0.207 & $* * *$ & $(0.025)$ & 0.916 & $* * *$ & (0.229) \\
\hline YEAR1998 & 0.480 & $* * *$ & $(0.043)$ & 0.217 & $* * *$ & $(0.025)$ & 0.814 & $* * *$ & $(0.225)$ \\
\hline YEAR1999 & 0.521 & $* * *$ & $(0.044)$ & 0.260 & $* * *$ & $(0.025)$ & 0.854 & $* * *$ & $(0.228)$ \\
\hline YEAR2000 & 0.618 & $* * *$ & $(0.043)$ & 0.279 & $* * *$ & $(0.024)$ & 0.948 & $* * *$ & $(0.224)$ \\
\hline YEAR2001 & 0.629 & $* * *$ & $(0.042)$ & 0.293 & $* * *$ & $(0.024)$ & 1.242 & $* * *$ & $(0.220)$ \\
\hline YEAR2002 & 0.704 & $* * *$ & $(0.042)$ & 0.350 & $* * *$ & $(0.024)$ & 1.096 & $* * *$ & $(0.220)$ \\
\hline YEAR2003 & 0.810 & $* * *$ & $(0.041)$ & 0.355 & $* * *$ & $(0.023)$ & 1.399 & $* * *$ & $(0.216)$ \\
\hline YEAR2004 & 0.898 & $* * *$ & $(0.042)$ & 0.409 & $* * *$ & $(0.024)$ & 1.854 & $* * *$ & (0.219) \\
\hline YEAR2005 & 1.043 & $* * *$ & $(0.042)$ & 0.458 & $* * *$ & $(0.024)$ & 1.754 & $* * *$ & $(0.220)$ \\
\hline YEAR2006 & 1.090 & $* * *$ & $(0.042)$ & 0.486 & $* * *$ & $(0.024)$ & 2.124 & $* * *$ & $(0.218)$ \\
\hline YEAR2007 & 1.066 & $* * *$ & $(0.041)$ & 0.471 & $* * *$ & $(0.023)$ & 2.186 & $* * *$ & $(0.216)$ \\
\hline YEAR2008 & 1.016 & $* * *$ & $(0.041)$ & 0.436 & $* * *$ & $(0.023)$ & 2.201 & $* * *$ & $(0.216)$ \\
\hline YEAR2009 & 1.012 & $* * *$ & $(0.042)$ & 0.432 & $* * *$ & $(0.024)$ & 2.211 & $* * *$ & (0.218) \\
\hline \multicolumn{10}{|l|}{ Loan characteristics } \\
\hline L_netanpo & -0.062 & $* * *$ & $(0.013)$ & 0.014 & $*$ & $(0.007)$ & -0.201 & $* * *$ & $(0.067)$ \\
\hline$L \_P R 1$ & -0.846 & $* * *$ & $(0.023)$ & -0.284 & $* * *$ & $(0.012)$ & -7.613 & $* * *$ & $(0.126)$ \\
\hline$L \_P R 2$ & -0.205 & $* * *$ & $(0.024)$ & -0.052 & $* * *$ & $(0.014)$ & -4.758 & $* * *$ & $(0.130)$ \\
\hline$L \_P R 3$ & 0.077 & $* * *$ & $(0.028)$ & 0.011 & & $(0.016)$ & -2.852 & $* * *$ & (0.145) \\
\hline$L \_P R 4$ & 0.084 & $* *$ & $(0.034)$ & 0.044 & $* *$ & $(0.019)$ & -1.960 & $* * *$ & $(0.174)$ \\
\hline \multicolumn{10}{|l|}{ Firm characte ris tics } \\
\hline F_lnSALES & 0.187 & $* * *$ & $(0.005)$ & 0.055 & $* * *$ & $(0.003)$ & 0.875 & $* * *$ & $(0.031)$ \\
\hline$F \_R O A$ & 0.292 & $* * *$ & $(0.067)$ & 0.220 & $* * *$ & (0.039) & 0.031 & & (0.351) \\
\hline$F \_C A P$ & -0.148 & $* * *$ & $(0.022)$ & -0.076 & $* * *$ & $(0.015)$ & -0.450 & $* * *$ & $(0.146)$ \\
\hline F_BUILD & 0.108 & $* * *$ & $(0.020)$ & -0.004 & & $(0.012)$ & 0.138 & & (0.099) \\
\hline$F \_A G E$ & -0.008 & $* * *$ & $(0.000)$ & -0.004 & $* * *$ & $(0.000)$ & -0.009 & $* * *$ & $(0.002)$ \\
\hline \multicolumn{10}{|l|}{ Bank characteristics } \\
\hline BK_MAIN & -0.015 & & $(0.014)$ & -0.014 & $*$ & $(0.008)$ & -0.163 & $* *$ & $(0.071)$ \\
\hline BK_TYPE1 & 0.168 & $* * *$ & $(0.021)$ & 0.050 & $* * *$ & $(0.012)$ & 0.869 & $* * *$ & $(0.107)$ \\
\hline BK_TYPE2 & 0.112 & $* * *$ & $(0.023)$ & 0.044 & $* * *$ & $(0.013)$ & 0.338 & $* * *$ & (0.122) \\
\hline BK_TYРE3 & 0.151 & $* * *$ & $(0.047)$ & 0.042 & & $(0.027)$ & 0.613 & $* *$ & $(0.243)$ \\
\hline BK_TYPE4 & -0.024 & & $(0.021)$ & -0.019 & & $(0.012)$ & -0.112 & & (0.109) \\
\hline BK_TYPE5 & 0.055 & & $(0.050)$ & -0.075 & $* * *$ & (0.029) & 3.231 & $* * *$ & $(0.261)$ \\
\hline BK_TYPE6 & -0.027 & & $(0.022)$ & -0.021 & $*$ & $(0.012)$ & -0.008 & & (0.113) \\
\hline \multicolumn{10}{|l|}{ Policy me asures } \\
\hline PL_ACTION & -0.049 & $* *$ & $(0.022)$ & -0.012 & & $(0.012)$ & 0.311 & $* * *$ & (0.113) \\
\hline PL_CEILING & -0.106 & & $(0.154)$ & -0.074 & & $(0.088)$ & -0.954 & & $(0.793)$ \\
\hline constant & 0.227 & $*$ & $(0.125)$ & -0.015 & & $(0.070)$ & 17.622 & $* * *$ & (0.684) \\
\hline Industry dummies & Yes & & & Yes & & & Yes & & \\
\hline Regional dummies & Yes & & & Yes & & & Yes & & \\
\hline NOB & 59125 & & & 59125 & & & 59125 & & \\
\hline Pseudo R2 & 0.0201 & & & 0.0134 & & & 0.0347 & & \\
\hline
\end{tabular}


Table 3 DID (difference-in-differences) of the ex-post performance for high- versus low-LTV borrowers

This table presents the results for the analysis on the DID (difference-in-differences) of the ex-post performance variables between high- versus non-high LTV borrower groups, where high-LTV ratios loans are defined as those in the fourth quartile of the entire LTV ratios. Year t refers to the year in which a loan was extended, and spans from 1990 to 2004. We evaluate the ex-post performance in years $\mathrm{t}+\mathrm{k}(\mathrm{k}=1,2, \ldots, 5)$ and use the differences (from year $\mathrm{t}$ to $\mathrm{t}+\mathrm{k})$ in the number of employee $\left(d_{-} F_{-} E M P\right)$, in sales in logarithm $\left(d_{-} D_{-} \ln S A L E S\right)$, in return on asset $\left(d_{-} F_{-} R O A\right)$, and in capital-asset ratio $\left(d \_F \_C A P\right)$. DID (difference-in-differences) indicates the difference in the average ex-post performance variable between the treatment group (firms with high LTV loans) and the control group (firms with non-high LTV loans). ***, **, * respectively indicate that the null hypothesis of the DID being zero is rejected at the significance level of 1,5 , and $10 \%$ levels. In panel (1), control observations are simple unmatched non-treatment firms. In panel (2), control observations are the 5-nearest matched non-treatment firms that have the closest propensity scores to each treatment observation. 


\begin{tabular}{|c|c|c|c|c|c|c|c|c|c|c|c|c|c|c|c|c|c|}
\hline \multicolumn{18}{|c|}{ (1) Unmatched control } \\
\hline & & \multirow{2}{*}{\multicolumn{4}{|c|}{$\begin{array}{l}\text { (A) Entire sample } \\
\text { Treatument Control }\end{array}$}} & \multicolumn{4}{|c|}{$\begin{array}{l}\text { (B) } 1990-1994 \\
\end{array}$} & \multicolumn{4}{|c|}{$\begin{array}{l}\text { (C) } 1995-1999 \\
\end{array}$} & \multicolumn{4}{|c|}{$\begin{array}{l}\text { (D) 2000-2004 } \\
\end{array}$} \\
\hline \multirow{6}{*}{$\overline{d_{-} F_{-} E M P}$} & & & & DID & S.E. & Treatment & Control & DID & S.E. & Treatment & Cont & DID & S.E & Treatment & Contr & ID & S.E. \\
\hline & $\mathrm{t}+1$ & 0.417 & 0.217 & $0.200 * * *$ & $\begin{array}{l}(0.065) \\
\end{array}$ & 1.463 & 0.673 & $0.789 * * *$ & $(0.206)$ & -0.022 & -0.155 & 0.133 & (0.161) & 0.165 & 0.087 & 0.078 & $(0.116)$ \\
\hline & $\mathrm{t}+2$ & 0.487 & 0.283 & 0.204 ** & $(0.102)$ & 2.070 & 1.001 & $1.069 * * *$ & $(0.314)$ & -0.477 & -0.575 & 0.098 & $(0.248)$ & 0.387 & 0.288 & 0.100 & $(0.186)$ \\
\hline & $t+3$ & 0.278 & 0.137 & 0.141 & $(0.133)$ & 2.128 & 0.817 & $1.311 * * *$ & $(0.404)$ & -1.497 & -1.252 & -0.246 & $(0.31$ & 0.459 & 0.486 & -0.027 & $(0.236)$ \\
\hline & $\mathrm{t}+4$ & 0.194 & 0.054 & 0.140 & $(0.166)$ & 2.074 & 0.402 & $1.672 * * *$ & $(0.469)$ & -2.472 & -1.857 & $-0.614 *$ & $(0.373)$ & 0.640 & 0.809 & -0.169 & $(0.281)$ \\
\hline & $t+5$ & 0.108 & -0.136 & 0.244 & $(0.199)$ & 1.427 & -0.337 & $1.764 * * *$ & $(0.527)$ & -3.009 & -2.326 & -0.682 & $(0.423)$ & .816 & 1.042 & -0.226 & $(0.317)$ \\
\hline \multirow[t]{5}{*}{$d_{-} F_{-} \ln S A L E S$} & $t+1$ & 0.008 & 0.007 & 0.001 & $(0.002)$ & 0.027 & 0.002 & $0.025 * * *$ & $(0.005)$ & 0.001 & 0.003 & -0.002 & $(0.005)$ & 014 & 0.019 & -0.006 & $(0.004)$ \\
\hline & $\mathrm{t}+2$ & 0.010 & 0.008 & 0.002 & $(0.003)$ & 0.031 & -0.005 & $0.036 * * *$ & $(0.007)$ & -0.018 & -0.007 & -0.011 & $(0.007)$ & .036 & 0.038 & -0.002 & $(0.006)$ \\
\hline & $t+3$ & 0.008 & 0.009 & -0.001 & $(0.004)$ & 0.048 & -0.004 & $0.052 * * *$ & $(0.009)$ & -0.043 & -0.029 & $-0.014 *$ & $(0.008)$ & 0.049 & 0.057 & -0.009 & $(0.007)$ \\
\hline & $\mathrm{t}+4$ & 0.005 & 0.008 & -0.003 & $(0.005)$ & 0.047 & -0.008 & $0.055 * * *$ & $(0.010)$ & -0.074 & -0.051 & $-0.023 * *$ & $(0.009)$ & 0.059 & 0.080 & $-0.021 * * *$ & $(0.008)$ \\
\hline & $t+5$ & -0.003 & 0.002 & -0.005 & $(0.005)$ & 0.029 & -0.023 & $0.052 * * *$ & $(0.011)$ & -0.085 & -0.059 & $-0.026 * *$ & $(0.011)$ & 0.042 & 0.072 & $-0.030 * * *$ & $(0.009)$ \\
\hline \multirow[t]{5}{*}{$d_{-} F_{-} R O A$} & $\mathrm{t}+1$ & -0.005 & -0.005 & 0.000 & $(0.001)$ & -0.007 & -0.007 & 0.001 & $(0.001)$ & -0.002 & -0.003 & 0.001 & $(0.001)$ & -0.003 & -0.002 & -0.001 & $(0.001)$ \\
\hline & $\mathrm{t}+2$ & -0.005 & -0.006 & 0.001 & $(0.0$ & -0.010 & -0.013 & $0.003 *$ & $(0.002)$ & -0.001 & -0.002 & & & -0.001 & -0.002 & & $(0.001)$ \\
\hline & $\mathrm{t}+3$ & $-0 . c$ & -0.008 & $0.001 * *$ & $(0$ & -0.012 & -0.017 & $0.005 * * *$ & $(0.0$ & 10 & -0.002 & & & -0. & -0.002 & & $(0.001)$ \\
\hline & $\mathrm{t}+4$ & -0.006 & -0.008 & $0.002^{* *}$ & $(0.0$ & -0.014 & -0.019 & $0.005 * * *$ & $(0.002)$ & 0.000 & -0.002 & & & -0.003 & -0.002 & -0 & $(0.001)$ \\
\hline & $t+5$ & -0.007 & -0.009 & $0.003 * * *$ & $(0.001)$ & -0.018 & -0.022 & $0.004 * *$ & $(0.002)$ & 0.001 & -0.001 & & (c) & -0.006 & -0.006 & 000 & $(0.001)$ \\
\hline \multirow[t]{5}{*}{$d_{-} F_{-} C A P$} & $t+1$ & -0.003 & -0.002 & -0.001 & $(0.001)$ & -0.003 & -0.001 & $-0.002 *$ & $(0.001)$ & 0.001 & 0.000 & 002 & $(0.1$ & 0.000 & 0.000 & .000 & $(0.001)$ \\
\hline & $\mathrm{t}+2$ & 0.001 & 0.002 & -0.001 & $(0.001)$ & 0.001 & 0.004 & -0.003 & $(0.002)$ & 0.009 & 0.005 & $0.004 * *$ & $(0.002)$ & 0.004 & 0.004 & .000 & $(0.002)$ \\
\hline & $t+3$ & 0.006 & 0.007 & -0.001 & $(0.001)$ & 0.007 & 0.008 & -0.001 & $(0.002)$ & 0.015 & 0.012 & 0.003 & $(0.002)$ & .008 & 0.008 & 0.000 & $(0.002)$ \\
\hline & $\mathrm{t}+4$ & 0.013 & 0.013 & -0.001 & $(0.001)$ & 0.012 & 0.014 & -0.002 & $(0.002)$ & 0.023 & 0.020 & 0.003 & $(0.002)$ & .013 & 0.012 & 0.000 & $(0.002)$ \\
\hline & $\mathrm{t}+5$ & 0.020 & 0.019 & 0.001 & $(0.001)$ & 0.019 & 0.019 & 0.000 & $(0.003)$ & 0.032 & 0.026 & $0.006 * *$ & $(0.003)$ & 0.018 & 0.017 & 0.001 & $(0.002)$ \\
\hline \multicolumn{18}{|c|}{ Matched control } \\
\hline & & \multicolumn{4}{|c|}{$\begin{array}{l}\text { Entire sample } \\
\end{array}$} & \multicolumn{4}{|l|}{$\begin{array}{l}1990-1994 \\
9\end{array}$} & \multirow{2}{*}{\multicolumn{4}{|c|}{$\begin{array}{l}1995-1999 \\
\end{array}$}} & \multirow{2}{*}{\multicolumn{4}{|c|}{ 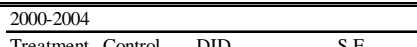 }} \\
\hline & & $\begin{array}{l}\text { Treatment } \\
\end{array}$ & Control & DID & S.E & Treatment & Control & DID & S.E. & & & & & & & & \\
\hline \multirow{5}{*}{$\overline{d_{-} F_{-} E M P}$} & $\mathrm{t}+1$ & 0.417 & 0.274 & $0.143 *$ & $(0.086)$ & 1.463 & 0.804 & $0.658 * * *$ & $(0.255)$ & -0.022 & -0.360 & 0.338 & $(0.208)$ & 0.165 & 0.270 & -0.105 & $(0.152)$ \\
\hline & $t+2$ & 0.4 & 0.193 & $0.294 * *$ & (0 & 2.070 & 1.139 & $0.931 * *$ & $(0.399)$ & -0.477 & -1.118 & $0.641 * *$ & & 0.387 & 0.351 & 0. & $(0.245)$ \\
\hline & $t+3$ & & -0.014 & $0.292 *$ & & 2.128 & 21 & $1.207 * *$ & & -1.497 & -2.119 & 0.622 & & 59 & 0.497 & -0.038 & $(0.310)$ \\
\hline & $\mathrm{t}+4$ & & & $0.386 *$ & & 2.074 & 0.262 & $1.812 * * *$ & $(0.585)$ & -2.472 & -3.269 & $0.798 *$ & $(0.481)$ & 0.640 & 0.802 & -0.162 & $(0.365)$ \\
\hline & $t+5$ & 0.108 & -0.570 & $0.678 * * *$ & $(0.260)$ & 1.427 & -0.804 & $2.231 * * *$ & $(0.660)$ & -3.009 & -3.624 & 0.615 & $(0.554)$ & 0.816 & 0.885 & -0.069 & $(0.413)$ \\
\hline \multirow[t]{5}{*}{$d_{-} F_{-} \ln S A L E S$} & $t+1$ & & 0.001 & $0.007 * *$ & $(0$. & 0.027 & 0.006 & $0.022 * * *$ & $(0.006)$ & 0.001 & -0.003 & 0.004 & $(0$. & 14 & 0.010 & 0.004 & $(0.005)$ \\
\hline & $\mathrm{t}+2$ & & 0.004 & 0.0 & & 0.031 & -0.001 & $0.032 * * *$ & $(0$. & -0.018 & -0.014 & -0.6 & (0 & 36 & 0.031 & 5 & $(0.007)$ \\
\hline & $t+3$ & & 0.003 & 0.00 & $(0.0$ & 0.048 & 0.004 & $0.044 * * *$ & $(0.010)$ & -0.043 & -0.041 & -0.6 & $(0$ & 49 & 0.047 & 01 & $(0.009)$ \\
\hline & $\mathrm{t}+4$ & & 0.001 & 0.0 & & & 0.001 & $0.046 * * *$ & $(0.011)$ & -0.074 & -0.069 & -0.0 & & & 0.069 & & $(0.010)$ \\
\hline & $t+5$ & & $-0 . c$ & & & & -0.015 & $0.044 * * *$ & & & -0.077 & & & & 0.051 & & 11) \\
\hline \multirow{5}{*}{$d_{-} F_{-} R O A$} & $\mathrm{t}+1$ & & & & & & & & & & & & & & & & \\
\hline & $\mathrm{t}+2$ & & & & & & & & & & & & & & & & \\
\hline & $t+3$ & & & & & & & & & & & & & & & & \\
\hline & $\mathrm{t}+4$ & & & & & & & & & & & & & & & & \\
\hline & $t+5$ & -0.6 & -0.008 & & & & -0. & 0.001 & & 0.001 & 0.001 & 0.000 & & -0.006 & -0.004 & & $(0.002)$ \\
\hline$d_{-} F_{-} C A P$ & $t+1$ & -0.003 & -0.002 & 0.000 & $(0.001)$ & -0.003 & 0.000 & $-0.003 * *$ & $(0.001)$ & 0.001 & 0.002 & 0.000 & $(0.001)$ & 0.000 & 0.000 & 0.000 & $(0.001)$ \\
\hline & $t+2$ & 0.001 & 0.002 & -0.001 & $(0.001)$ & 0.001 & 0.004 & -0.003 & $(0.002)$ & 0.009 & 0.008 & 0.002 & $(0.002)$ & 0.004 & 0.004 & 0.000 & $(0.002)$ \\
\hline & $t+3$ & 0.006 & 0.007 & -0.001 & $(0.6$ & 0.007 & 0.009 & -0.002 & $(0.002)$ & 0.015 & 0.013 & 0.002 & $(0.002)$ & 0.008 & 0.006 & 0.001 & $(0.002)$ \\
\hline & $\mathrm{t}+4$ & 0.013 & 0.012 & 0.000 & $(0.002)$ & 0.012 & 0.014 & -0.001 & $(0.003)$ & 0.023 & 0.021 & 0.002 & $(0.003)$ & 0.013 & 0.011 & 0.002 & $(0.003)$ \\
\hline & $t+5$ & 0.020 & 0.018 & 0.002 & $(0.002)$ & 0.019 & 0.020 & -0.001 & $(0.003)$ & 0.032 & 0.025 & $0.007 * *$ & $(0.003)$ & 0.018 & 0.015 & 0.003 & $(0.003)$ \\
\hline
\end{tabular}




\section{For Online Publication}

\section{Appendix A: Estimation of the current value of land}

\section{A.1 Hedonic approach}

As explained in section 3.2, the denominator of the LTV ratio, $\mathrm{V}$ (the per-acreage price of the land), is estimated using the hedonic approach that is widely used in the field of real estate economics. This approach assumes that the price of a land is the sum of the values of its attributes such as size, a floor area ratio, a physical distance to metropolis in the region, and so on (see Ohnishi et al., 2011). In particular, we assume that the $\log$ price of a $\operatorname{land} i, \log P_{i}$, is the sum of K components:

$$
\log P_{i}=\sum_{k=1}^{K} x_{i k} .
$$

In the actual estimation, we follow the following steps. First, using the dataset of "Public notice of land prices (PNLP)" provided by the Land Appraisal Committee of the Ministry of Land, Infrastructure, Transport and Tourism of the Government of Japan, we estimate a hedonic model where the log price of lands complied in PNLP is explained by different explanatory variables. The explanatory variables in this estimation are:

- $\quad$ the size of land in logarithm

- a regulatory upper limit of the floor area ratio

- an Euclidean distance from the relevant land to the one whose price is the highest in the same prefecture

- the square term of the Euclidean distance

- an Euclidean distance from the land to the one whose price is the highest in the same city

- $\quad$ the square term of the distance, the latitude of the land and its square term

- the longitude of the land and its square term 
- dummy variables representing the type of land districts where the land is located (i.e., whether the land is located in a residential, commercial, or industrialized district).

We run jillion of regressions for different combinations of land district type (residential, commercial, or industrialized), year, and region. As a unit for the regions, we in principle use prefecture, but in the case when the number of observations in a prefecture is not large enough to warrant trustable estimation results, we use an area including several neighboring prefectures as a unit for the region. However, this is the case only for a subset of the industrialized lands.

Second, based on the parameters obtained from the estimation of the above regressions, we project (predict) the current prices of the land in our dataset. We need to predict these prices because the number of the pieces of land in our dataset is far larger than that in the PNLP dataset. We have different sets of parameters depending on land district type, year, and region (obtained from the first stage estimations). When we project the price of a particular piece of land in our dataset, we use the parameters for the same land district type, year, and region. ${ }^{41}$

Finally, the value of the land is obtained by multiplying its projected price and the acreage obtained from the TDB database.

${ }^{41}$ For example, suppose land A in the TDB dataset is in a residential district in Tokyo prefecture in year 1990. In this case, its current price is projected using the parameters estimated for the sample in the residential district in Tokyo in 1990 (same-district, same-prefecture, and same-year) using the PNLP dataset. 


\section{A.2 Estimation Results (First Stage)}

As for the first stage estimation of hedonic models, the numbers of the regressions that we run for lands in residential districts and in commercial districts are both 1,738 (= 47 prefectures times 37 years, except for Okinawa in year 1975), and that for lands in industrial districts is 555 (15 regions times 37 years).

Figure A-1: In-sample comparisons between cumulative distributions of estimated and actual prices (PNLP)

[Residential land]

[Estimation]

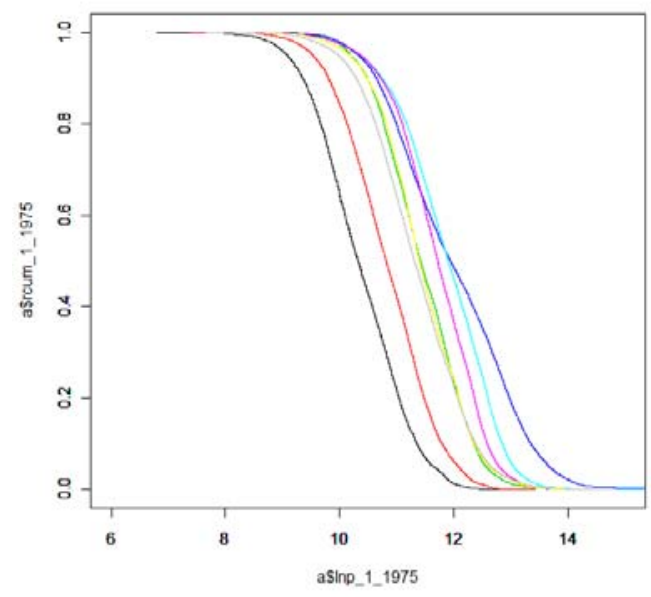

[Actual]

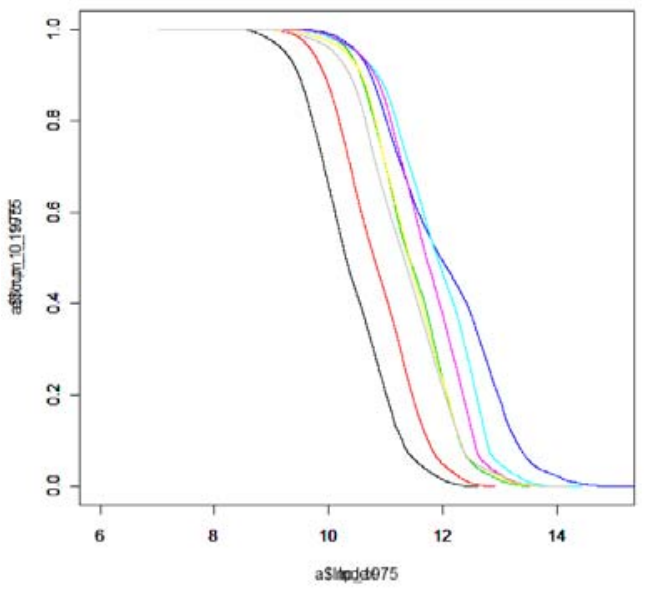

[Commercial land]

[Estimation]

[Actual] 

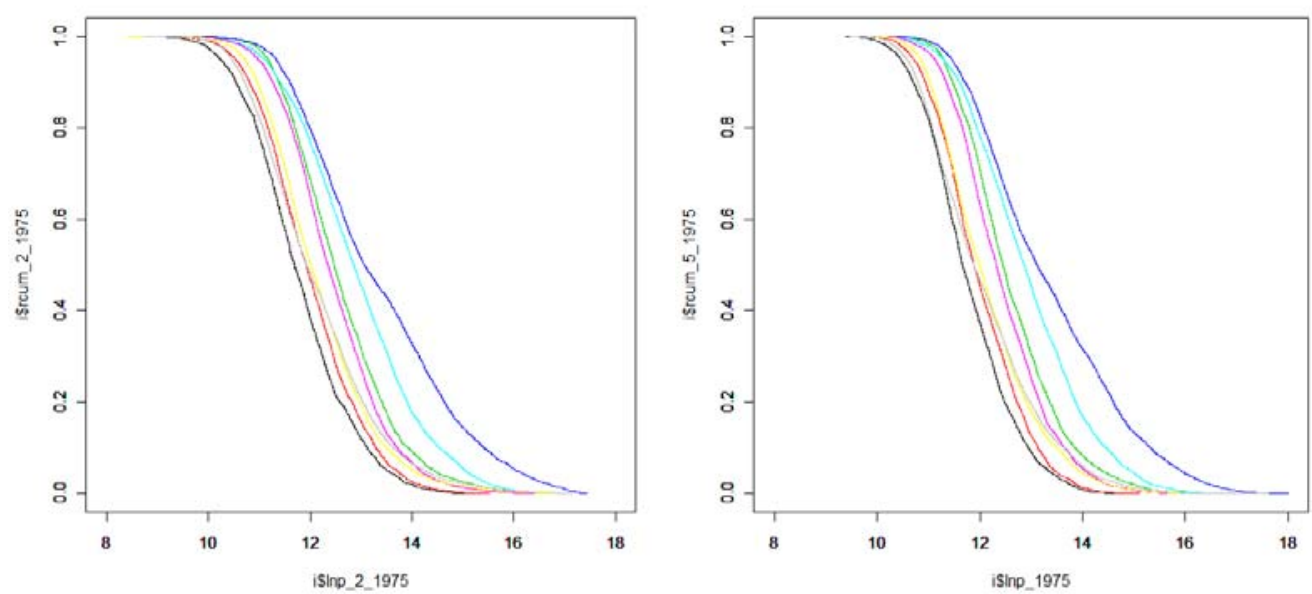

[Industrial land]

[Estimation]

[Actual]
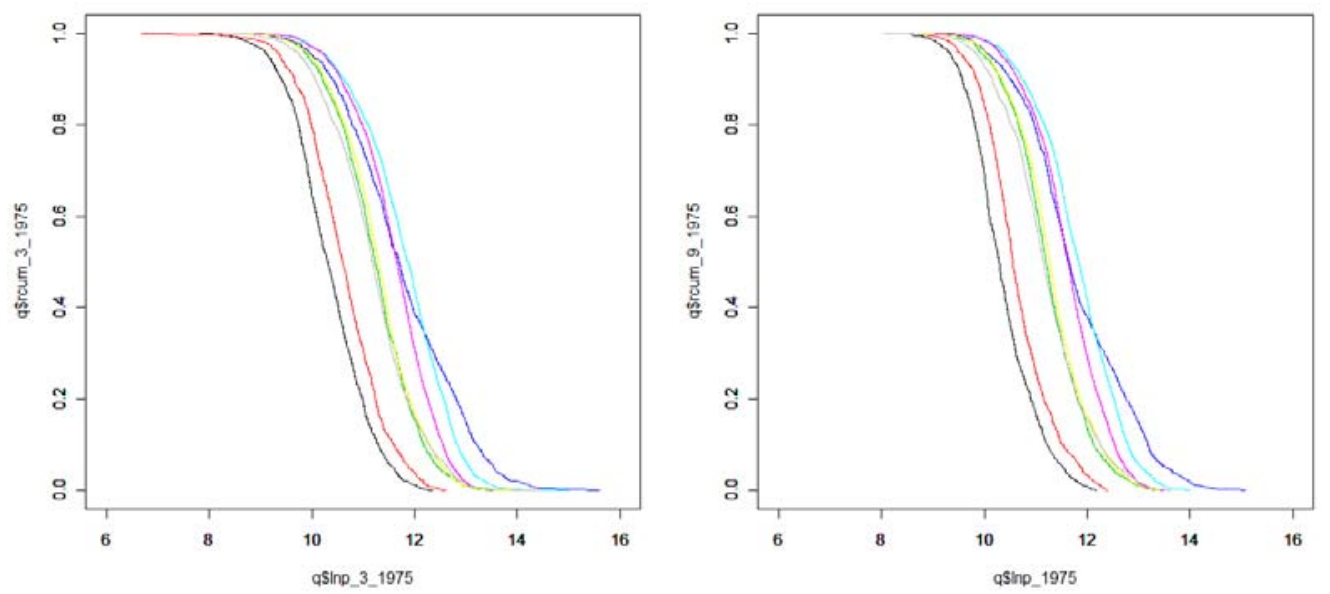

Notes: Each colored-line represents the following year: black 1975, red 1980, green 1985, blue 1990, light blue 1995, purple 2000, yellow 2005, and grey 2010.

To confirm the accuracy of the prediction using the coefficients obtained from the hedonic estimation, in-sample comparisons are shown in figure A-1. In the figure, we show the cumulative distributions of the predicted prices (left panels) and the actual PNLP prices (right panels) of the lands in the PNLP dataset for each of the three types of land districts. We find that the distributions are 
similar in all the panels, which justifies the prediction using the estimated coefficients.

\section{A.3 Projection Results (Second Stage)}

Based on the coefficients estimated in the first stage, we project the prices of each piece of land in our dataset. In doing so, we excluded outliers from our sample in the following manner. For each combination of land district type, prefecture, and year, we dropped observations whose projected prices were higher than the highest price of lands in the corresponding combination in the PNLP dataset. We also dropped those observations whose projected prices were lower than the lowest price in the PNLP database in the relevant year.

Figure A-2: Pot-of-sample comparisons between cumulative distributions of projected prices on the TDB dataset and actual prices in the PNLP dataset

[Residential land]

[Projection (TDB)]

[Actual (PNLP)]
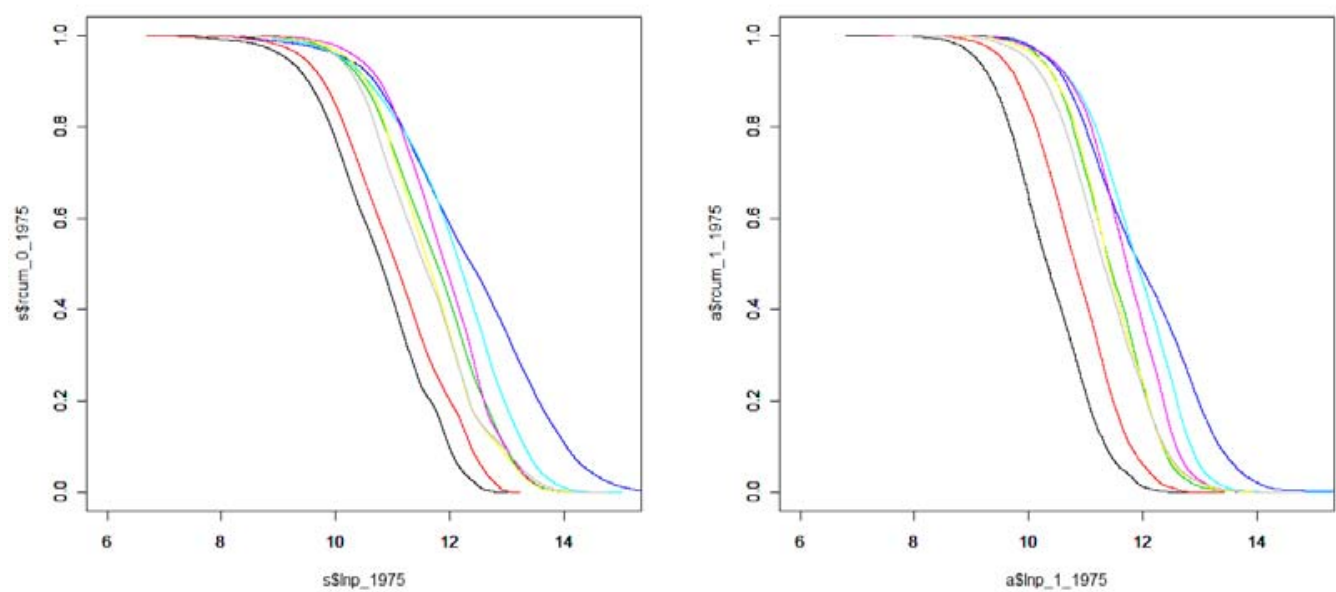

[Commercial land] 
[Projection (TDB)]

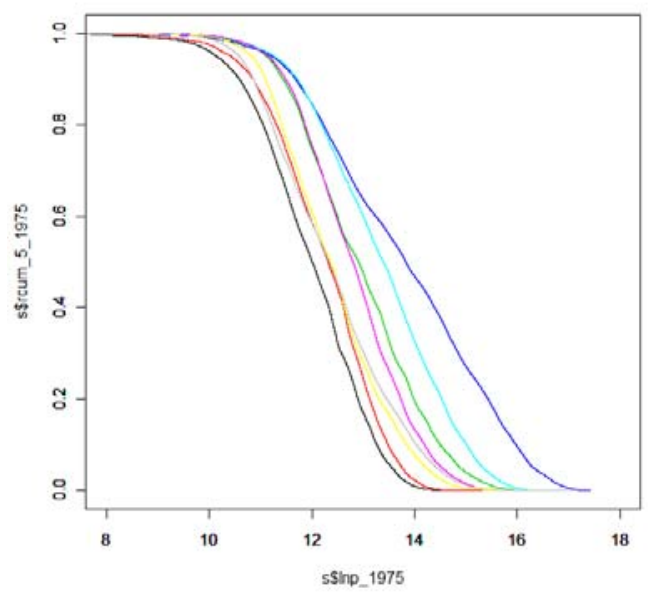

[Actual (PNLP)]

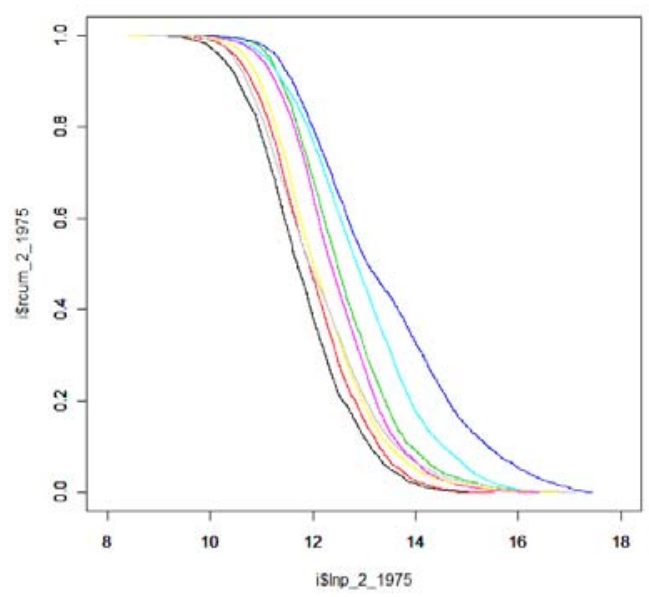

[Industrial land]

[Projection (TDB)]

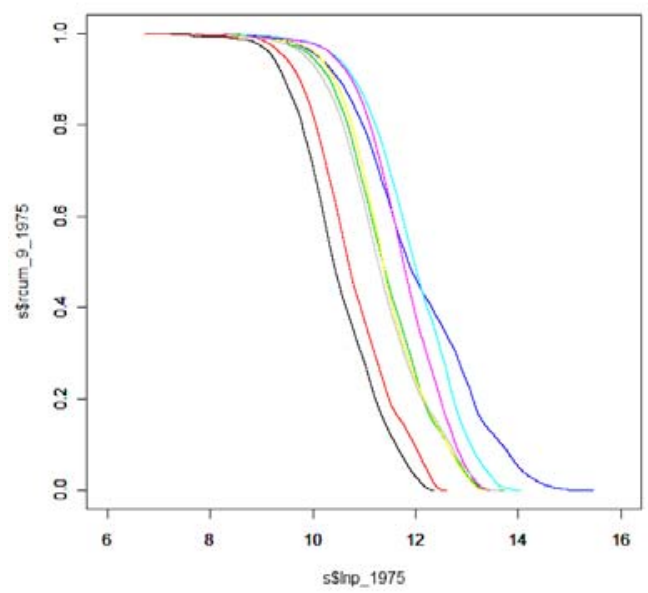

[Actual (PNLP)]

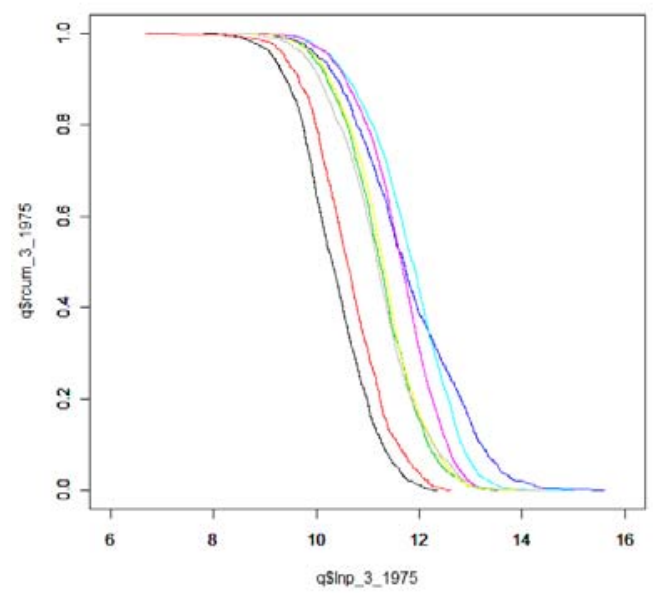

Notes: Each colored-line represents the following year: black 1975, red 1980, green 1985, blue 1990, light blue 1995, purple 2000, yellow 2005, and gray 2010

Figure A-2 shows the cumulative distributions of the projected prices of lands in our TDB dataset (left panels) and the actual prices in the PNLP data (right panels) for each type of land districts. Although the projected prices are available for a larger number of lands than the actual prices in the PNLP data, 
their distributions are similar, which supports our use of the projected prices to calculate the LTV ratios.

\section{Appendix B: Calculation of LTV ratios: an illustration}

Suppose that a firm owns four pieces of real estate (numbered from 1 to 4), and borrows using six loans, two from Bank Alpha, two from Bank Beta, and two from Bank Gamma (see Figure B-1). The firm pledges its properties as collateral to these banks: Land 1 is pledged to loan A extended by Bank Alpha in year 1985; land 2 is pledged to loan B extended by Beta in 1990 and is also pledged to loan F extended by Gamma in 1995; land 3 is pledged to loan C extended by Beta in 2000 and is also pledged to loan F by Gamma in 1995; and land 4 is pledged to loan $\mathrm{D}$ extended by Alpha and is also pledged to loan $\mathrm{E}$ extended by Gamma, and both pledged are registered on the same date in 2005 .

Calculation is fairly simple if a land is pledged to only one claim holder. In the example above, this is the case for loan A. Information about the amount of loan A, represented by LA, is provided by TDB database. The value of land A in year 1985, V1(1985), is estimated by the hedonic approach described in Ono et al. (2013). The LTV ratio for loan A (LTV_A(1985)) is simply obtained by dividing LA by V1(1985).

If a piece of land is pledged to multiple claim holders (and loans) and/or if multiple pieces of land are pledged to one claim holder, the calculation of the LTV ratio becomes complicated. The calculation differs depending on the seniority among different loans. As noted above, we assume that a claim holder is senior to other claim holders if the date of its registration predates those of the others. 
In the example above, land 2 is pledged to loan $\mathrm{B}$ as well as to loan $\mathrm{F}$. Because loan B (originated in year 1990) was extended prior to loan F (in year 1995), we assume that loan B is senior to loan F. The LTV ratio of loan B is calculated in the same manner as in the case with one claim holder: LTV_B(1990)=LB/V2(1990).

The calculation also differs for junior loans. In this example, land 3 is pledged to loan C as well as to loan F, and the former (underwritten in year 2000 by Beta) is subordinated to the latter (underwritten in year 1995 by Gamma). In this case, the amount of the senior loan (loan F) should be taken into account when calculating the LTV ratio for loan C. That is, the LTV ratio that properly expresses the exposure defined above for Bank Beta is LTV_C(2000)=(LF+LC)/V2(1995). The calculation is similar if there are several loans with the same registration date, in which case we assume that they have the same rank of priority. In the example above, land 4 is pledged to loan $\mathrm{D}$ and loan E that are extended respectively by Alpha and Gamma on the same date. In this case, LTV_D(2005)=LTV_E(2005)=(LD+LE)/V4(2005).

The most complicated is the LTV ratio for a loan to which multiple properties are pledged as collateral. In our example, Loan $\mathrm{F}$ extended by Gamma is backed by two properties, land 2 and land 3. As for land 2, Gamma is junior to Beta, whereas for land 3, it is the most senior lender. In this case, we cannot define the LTV ratio in a suitable manner, because the ratio cannot be conceptualized in terms of bank exposure in this a situation. Thus, we decided to eliminate such observations from the sample of our empirical analysis. The number of observations eliminated in this manner is, however, small. Also note 
that the LTV ratio of a loan secured by multiple properties can be well defined as long as the rank of seniority is the same among all properties. For example, if loan $\mathrm{F}$ were a senior loan for both land 2 and land 3, then LTV_F(1995) = $\mathrm{LF} /(\mathrm{V} 2(1995)+\mathrm{V} 3(1995))$. In a similar vein, if instead loan F were junior, then LTV_F(1995) $=(\mathrm{LB}+\mathrm{LC}+\mathrm{LF}) /(\mathrm{V} 2(1995)+\mathrm{V} 3(1995))$

\section{Figure B-1 Illustrative setting for LTV calculation}

\begin{tabular}{|c|c|c|c|c|c|}
\hline Mortgagee & Loan ID & $\begin{array}{l}\text { Amount } \\
\text { of loan }\end{array}$ & $\begin{array}{c}\text { Year of } \\
\text { registration }\end{array}$ & Land ID & Value of land \\
\hline Alpha & $\mathrm{A}$ & LA & 1985 & 1 & V1(1985) \\
\hline Beta & $\mathrm{B}$ & LB & 1990 & 2 & V2(1990), V2(1995) \\
\hline Beta & $\mathrm{C}$ & $\mathrm{LC}$ & 2000 & 3 & V3(1995), V3(2000) \\
\hline Alpha & $\mathrm{D}$ & LD & 2005 & 4 & V4(2005) \\
\hline Gamma & $\mathrm{E}$ & LE & 2005 & & \\
\hline Gamma & $\mathrm{F}$ & $\mathrm{LF}$ & 1995 & & \\
\hline
\end{tabular}

